\title{
Antimicrobial activity, toxicity and phytochemical screening of selected medicinal plants of Losho, Narok County, Kenya
}

\author{
DUNCAN MUTISO CHALO ${ }^{1}$, CATHERINE LUKHOBA ${ }^{1, \bullet}$, DOSSAJI SAIFUDDIN FIDAHUSSEIN ${ }^{1}$, \\ JOSEPH MWANZIA NGUTA ${ }^{2}$ \\ ${ }^{1}$ School of Biological Sciences, College of Biological and Physical Sciences, University of Nairobi. Nairobi, Kenya. P.O Box 30197, Nairobi, Kenya. \\ Tel.: +254 44 42316, `email: clukhoba@uonbi.ac.ke, clukhoba@yahoo.co.uk \\ ${ }^{2}$ Department of Public Health, Pharmacology and Toxicology, Faculty of Veterinary Medicine, College of Agriculture and Veterinary Sciences, \\ University of Nairobi, Nairobi, Kenya.
}

Manuscript received: 10 November 2016. Revision accepted: 22 February 2017.

\begin{abstract}
Chalo DM, Lukhoba C, Fidahussein DS, Nguta JM. 2017. Antimicrobial activity, toxicity and phytochemical screening of selected medicinal plants of Losho, Narok County, Kenya. Biofarmasi J Nat Prod Biochem 15: 29-43. In Kenya, microbial infections are a major cause of morbidity. The effectiveness of antibiotics is threatened by the increase of resistance of pathogenic microbes against most available drugs because new pathogens continue to emerge. Nowadays, herbal remedies offer hope since they are readily available and cheap. The aim of this research was to investigate the activity of antimicrobial, the lethality of brine shrimp, and the phytochemical composition of crude extracts of four selected plants, namely Schrebera alata (Oleaceae), Ormocarpum kirkii (Papilionoideae), Helichrysum forskahlii (Asteraceae) and Cussonia holstii (Araliaceae) that herbalists medicinally use from Losho, Narok County Kenya for treatment of ear, nose and throat infections, gastrointestinal disorders and skin diseases. Using agar, a qualitative antimicrobial susceptibility test against five microorganisms, methicillin-resistant Staphylococcus aureus, Bacillus cereus, Escherichia coli, Pseudomonas aeruginosa, and Candida albicans was investigated diffusion methods to produce inhibition zones, and the data accrued were analyzed using Analysis of variance. Minimum inhibitory concentrations were determined by the broth microdilution method. The toxicity of the extracts was analyzed using a brine shrimp lethality assay. The median fatal concentration of fifty was determined by data analysis using Finneyes computer program. Phytochemical screening for flavonoids, sterols, alkaloids, tannins, quinones, terpenoids, and saponins was determined using standard procedures. The observation showed that the organic crude extracts of $H$. forskahlii had the highest inhibition zone against methicillin-resistant $S$. aureus of 19.5 and $18.5 \mathrm{~mm}$ in agar well and agar disk diffusion, respectively. In addition, organic extracts of $H$. forskahlii showed the highest antifungal inhibition zone of $8.5 \mathrm{~mm}$ in agar well diffusion. Minimum values of inhibitory concentrations varied from 15.625 to $250 \mathrm{mg} / \mathrm{mL}$. Organic crude extracts of $H$. forskahlii and $C$. holstii were highly toxic, with a lethal concentration of $0.009 \mathrm{mg} / \mathrm{mL}$. All plant crude extracts contained flavonoids, sterols, alkaloids, tannins, quinones, and terpenoids. Saponins were present in all the plant extracts except in the organic extracts of $H$. forskahlii. This study promoted the first record of antimicrobial activity, toxicity, and phytochemical composition of $S$. alata and $C$. holstii. The study has shown that $H$. forskahlii and $O$. kirkii possess promising antimicrobial activity against microbes of health importance and could isolate new, safe, and efficacious antimicrobial compounds. Further research should be carried out on $O$. kirkii and S. alata to isolate and characterize the compounds responsible for the observed activity.
\end{abstract}

Keywords: Antimicrobial activity, Brine shrimp lethality assay, Kenya, Losho, Medicinal plants, Narok, phytochemical composition

\section{INTRODUCTION}

Microbial infections remain a threat to millions of lives globally (Kalita et al., 2012). Nowadays, there is an increasing problem of antibiotic resistance due to microbial persistence (Kitonde et al., 2013). The rapid rise in microbial resistance to synthetic drugs has urged the formulation of new antimicrobial agents and the evaluation of the efficacy of natural plant products as a substitute for chemical antimicrobial agents (Pandian et al. 2006). Traditional medicine is either the mainstay of health care delivery or serves to complement it worldwide (WHO 2008). The World Health Organization in 2008 estimated that up to $80 \%$ of the population in some developing countries use traditional medicine. Traditional medicine has been recognized as a part of primary health care programs in many African countries. In Kenya, rich pharmacopeia systems have been documented for communities like Maasai, Gusii, Luo, Abaluhyia, and Kikuyu (Kokwaro 2009).

According to WHO (2002) and Pandey et al. (2011), a medicinal plant contains substances that can be used for therapeutic purposes or precursors of chemopharmaceuticals semi-synthetic new drugs. Phytochemicals offer a unique platform for structural diversity and biological functionality, which is indispensable for drug discovery. Plants have an almost limitless ability to synthesize secondary metabolites, which may have a defensive role against herbivores, pathogen attacks, and interplay competition. Moreover, these metabolites act as an attractant for pollinators or symbionts. Many naturally occurring compounds in plants possess antimicrobial 
functions and serve as antimicrobial agents (Kalita et al., 2012).

Like in other African countries, in Kenya, traditional medicine is practiced to treat sexually transmitted diseases, eye infections, skin-related problems, wounds, gastrointestinal diseases, measles, and snake bites (Njoroge and Bussmann 2007; Kokwaro 2009; Odhiambo et al. 2010). Microbial infections such as tuberculosis, candidiasis, cryptococcosis, and salmonellosis have increased in the recent past, partially due to HIV/AIDS pandemic (Mwitari et al., 2013). At the same time, antibiotics are becoming less and less efficacious against microbial illnesses due to the emergence of drug-resistant bacteria. Natural products of higher plants may give new sources of antimicrobial agents with possibly novel mechanisms of action (Bhalodia and Shukla 2011). According to Kokwaro (2009), overdosed patients, due to the imprecise diagnosis, are worldwide. Toxic effects have been attributed to certain active principles found in plants (Nguta et al., 2011).

The Maasai of Losho, who are mainly pastoralists, not only depends on plants for food, fuel, and wood but also for medicine in rituals and ceremonies (Karehed and Odhult 1997). However, many of these plants have not been investigated for phytochemical composition, antimicrobial, and toxicity activities. Therefore, this study aimed to evaluate the antimicrobial activity, brine shrimp lethality, and phytochemical composition of crude extracts from Schrebera alata, Ormocarpum kirkii, Helichrysum forskahlii, and the the Cussonia holstii. These plants are majorly used as traditional medicine for the currency of skin diseases, gastrointestinal tract diseases, and respiratory problems.

Antibiotic resistance has become a global concern due to an increased incidence of multiple resistances in human pathogenic microorganisms in recent years, largely due to the indiscriminate use of commercial antimicrobial drugs commonly employed in treating infectious diseases (Adenisa et al. 2000). Drugs from plant sources are keyway to addressing the problem. Also, synthetic antibiotics are not only expensive; but also have side effects in the treatment of infectious diseases (Kone et al. 2004).

Many communities, especially rural areas, still rely on herbal remedies in Kenya. Nowadays, there is little information regarding the literature on medicinal plants in Kenya (Kigen et al., 2013). Several drugs have been derived directly or indirectly from plants, including digoxin, taxol, vinblastine, nabilone, and artemisinin (Cragg and Newman 2005).

The objectives of this research were (i) To evaluate the antimicrobial potential of the crude plant extracts against Pseudomonas aeruginosa, Escherichia coli, methicillinresistant Staphylococcus aureus (MRSA), Bacillus cereus, and Candida albicans, (ii) To determine the acute toxicity of the crude plant extracts using brine shrimp (Artemia salina) lethality assay, (iii) To investigate the presence of major phytochemical constituents in the crude plant extracts.

\section{MATERIALS AND METHODS}

\section{Collection of plant materials}

Four plants that were selected based on their ethnomedicinal usage were collected from Losho, Narok County, Kenya, with the help of herbalists (Table 1). The bark stems of Schrebera alata and Cussonia holstii were peeled; aerial parts of Ormocarpum kirkii were cut and chopped into pieces, while the whole plant of Helichrysum forskahlii (the herb) was uprooted. Their parts of plants were stuffed in a polythene bag, placed in a cooler box, and transported to Nairobi. They were thoroughly washed with running water and dried at room temperature for six weeks after being ground into a fine powder using an electric mill.

Plant specimens were collected in duplicate; one unit of the specimen was used for preliminary identification in the field as previously described (Agnew and Agnew 1994), while the other was pressed and carried to the University of Nairobi Herbarium for authentication and further compared with the available herbarium collections which were permanently prepared.

\section{Preparation of crude extracts \\ Preparation of organic extracts.}

According to standard extraction methods, Dichloromethane/methanol (1: 1) was used to extract 50g of ground material by cold solvent percolation. The plant material powder was mixed thoroughly with the solvent, left to stand for $24 \mathrm{hrs}$, and decanted (repeated twice). The filtrates were pooled and filtered using a Buchner funnel. After the dissolution of the solvents at $40^{\circ} \mathrm{C}$ to obtain crude extracts, dichloromethane and methanol extracts were obtained. These were then stored in airtight containers at $4^{\circ} \mathrm{C}$ and prepared for bioassay and phytochemical screening (Odhiambo et al., 2014).

\section{Preparation of aqueous extracts}

The ground materials were extracted by the cold maceration method. To obtain aqueous extracts, fifty grams of ground plant material were extracted with distilled water $(500 \mathrm{~mL})$. The aqueous extracts were filtered, and the filtrate was kept in a deep freezer, then lyophilized (freezedried), resulting in a dry powder, and then stored in airtight containers at $4^{\circ} \mathrm{C}$ being prepared for bioassays and phytochemical screening (Odhiambo et al. 2014).

\section{Media preparation \\ Mueller Hinton Agar}

Fifty-eight grams of MHA medium was suspended in $1000 \mathrm{~mL}$ distilled water. Heating to boiling to dissolve the medium completely was done, followed by sterilization by autoclaving at $15 \mathrm{lbs}$ pressure $\left(121^{\circ} \mathrm{C}\right)$ for 15 minutes. Mixing was done well before pouring (Bauer et al. 1966). 
Table 1. Voucher specimens and plants parts collected from Losho, Narok County, Kenya

\begin{tabular}{llll}
\hline $\begin{array}{l}\text { Voucher } \\
\text { specimen } \\
\text { number }\end{array}$ & Plant species & Family & $\begin{array}{l}\text { Part } \\
\text { collected }\end{array}$ \\
\hline DMC2014/001 & $\begin{array}{l}\text { Schrebera alata } \\
\text { (Hochst.) Welw. }\end{array}$ & Oleaceae & Bark \\
DMC2014/002 & $\begin{array}{l}\text { Ormocarpum kirkii } \\
\text { (Taub.) Engl. }\end{array}$ & Fabaceae & Aerial part \\
DMC2014/003 & $\begin{array}{l}\text { Cussonia holstii } \\
\text { Harms ex Engl. }\end{array}$ & Araliaceae & Bark \\
DMC2014/004 $\begin{array}{l}\text { Helichrysum forskahlii } \\
\text { (J.F. Asteraceae }\end{array}$ & $\begin{array}{l}\text { Whole Hilliard \& } \\
\text { plant }\end{array}$ \\
& B.L. Burttv. & & \\
\hline
\end{tabular}

Table 2. List of microbes tested in the study

\begin{tabular}{|c|c|c|c|}
\hline Name of microbe & $\begin{array}{l}\text { Microbe } \\
\text { type }\end{array}$ & $\begin{array}{l}\text { Gram strain } \\
\text { type }\end{array}$ & $\begin{array}{l}\text { Details of } \\
\text { strain used }\end{array}$ \\
\hline & Bacteria & Gram-positive & ATCC 11778 \\
\hline & & & 385 \\
\hline Pseudomonas & $\mathrm{a}$ & ve & 7823 \\
\hline Esche & $\mathrm{ac}$ & Gra & ATCC 25922 \\
\hline Candida albicans & Fungus & - & ATCC10231 \\
\hline
\end{tabular}

\section{Sabouraud Dextrose Agar}

Sixty-five grams of the medium were suspended in one liter of purified water, heated with frequent agitation, boiled for one minute to dissolve the medium completely, then autoclaved at $121^{\circ} \mathrm{C}$ for 15 minutes. The prepared media was stored at $8-15^{\circ} \mathrm{C}$ (Murray et al. 2003).

\section{Source of microorganisms}

The micro-organisms methicillin-resistant Staphylococcus aureus (MRSA) and Pseudomonas aeruginosa were obtained from KEMRI, Centre for Microbiology Research (CMR), while Bacillus cereus, Escherichia coli, and Candida albicans were from the Department of Public health, Pharmacology, and Toxicology, University of Nairobi, Kenya (Table 2).

\section{Subculturing of test microorganisms.}

Subculturing of the test strains was done in the following procedure. Bacteria were proliferated in MullerHinton agar for $18 \mathrm{hrs}$, and fungi were proliferated in Sabouraud Dextrose agar for $48 \mathrm{hrs}$ to obtain freshly growing strains. The microbial suspensions were standardized according to the Clinical and Laboratory Standards.

Institute procedures (CLSI 2009 for bacteria) and (CLSI 2008 for fungi) with sterile saline to a turbidity equivalent to $0.5 \mathrm{McFarland}$ (approximately $1.5 \times 10^{8} \mathrm{CFU} / \mathrm{mL}$ for bacteria and $1.5 \times 10^{6} \mathrm{CFU} / \mathrm{mL}$ for Candida sp.) and stored at $4{ }^{\circ} \mathrm{C}$ until they were used during the antimicrobial test.

\section{Antimicrobial susceptibility testing}

Agar diffusion methods which followed National Committee for Clinical Laboratory Standards (CLSI 2009) procedures, were used to evaluate the antimicrobial activities of the crude extracts. Twenty $\mathrm{mL}$ of sterile Muller-Hinton Agar and Sabouraud Dextrose Agar were poured into sterile petri plates and allowed to be set. An inoculum suspension was swabbed uniformly to solidify 20 $\mathrm{mL}$ Mueller-Hinton Agar (MHA) for bacteria and Sabouraud Dextrose Agar (SDA) for fungi. The inoculum was allowed to dry for $5 \mathrm{~min}$. Three concentrations (400, 200 , and $100 \mathrm{mg} / \mathrm{mL}$ ) of each test extract (organic extracts and aqueous extracts of S. alata, C. holstii, O. kirkii, and $\mathrm{H}$. forskahlii) were prepared for susceptibility testing using $1 \%$ of DMSO for organic extracts and distilled water for aqueous extracts.

Agar well diffusion. Holes of $10 \mathrm{~mm}$ diameter were made in the seeded agar using a sterile cork borer.100 $\mu$ of the test extracts were inserted into the wells using a microtiter-pipette and allowed to stand on the bench for $1 \mathrm{~h}$ for proper disperse into the agar and, after that, incubated at $24 \mathrm{hrs}$ at $37^{\circ} \mathrm{C}$. Microbial growth was determined by measuring the diameter of the zone of inhibition in millimeters (mm). For each microbial strain, controls were maintained where pure solvents were used instead of the crude extracts (Parekh and Chanda 2007). The experiment was undergone in triplicates under sterile conditions, and the mean values were obtained.

Disc diffusion. Commercially prepared sterile discs of $6 \mathrm{~mm}$ diameter were infused with $100 \mu \mathrm{l}$ of each crude extract dried and deposited aseptically onto plates inoculated with a $1 \mathrm{~mL}$ overnight growth test microorganism. Bacterial and fungal cultures were incubated for $24 \mathrm{hrs}$ at $37^{\circ} \mathrm{C}$ for bacteria and $37^{\circ} \mathrm{C}$ for 72 hrs for fungi. Chloramphenicol $30 \mu \mathrm{g} / \mathrm{mL}$ (for bacteria) and Amphotericin B $30 \mu \mathrm{g} / \mathrm{mL}$ (for fungi) were used as positive controls, while discs with diluting solvents only were used as negative controls. Each extract was tested in triplicate under sterile conditions. Microbial growth was determined by measuring the diameter zone of inhibition in millimeters (Kitonde et al., 2013).

\section{Determination of Minimum Inhibitory Concentration (MIC)}

The broth microdilution method was utilized to decide the least inhibitory convergence for the exertive unrefined extracts against the test microorganisms. As the National Committee for Clinical Laboratory Standards suggested, the scheme was now the Clinical Laboratory Standard Institute (CLSI) (Ferraro 2003). $0.5 \mathrm{~mL}$ of $24 \mathrm{~h}$ culture of the test organism $\left(10^{7} \mathrm{CFU} / \mathrm{mL}\right)$ changed in accordance with McFarland turbidity standard $0.5 \mathrm{McFarland}$ (around $1.5 \times 10^{8} \mathrm{CFU} / \mathrm{mL}$ for bacteria and $1.5 \times 10^{6} \mathrm{CFU} / \mathrm{mL}$ for Candida $s p$. Were incubated in serial dilution $250 \mathrm{mg} / \mathrm{mL}$, $125 \mathrm{mg} / \mathrm{mL}, 62.5 \mathrm{mg} / \mathrm{mL}, 31.25 \mathrm{mg} / \mathrm{mL}, 15.625 \mathrm{mg} / \mathrm{mL}$. Incubation was done for $24 \mathrm{hrs}$ at $37{ }^{\circ} \mathrm{C}$. Minimal centralization of the plant separation did not allow any noticeable development of the vaccinated test microorganism in broth culture. The absence of turbidity was viewed as the visual MIC for each situation (Michael et al., 2003). Tubes that were inoculated with microbes alone and media alone served as control. All the experiments were done in triplicates, and the results were recorded. 
Determination of acute toxicity of crude extracts

The crucial toxicity assay was performed using brine shrimp nauplii based on the Meyer method (Nguta et al. 2013). Artificial seawater was prepared by liquefying 38 grams of sea salt in $1 \mathrm{~L}$ of distilled water. A tank with the size of $14 \mathrm{~cm}$ by $9 \mathrm{~cm}$ by $5 \mathrm{~cm}$ having two unequal compartment chambers with several holes on the divider was used for hatching. The chambers were filled with artificial seawater. Brine shrimp eggs were placed in the larger compartment, and yeast was added to act as food for the nauplii. The larger compartment was then covered with dark background paper while the smaller compartment was illuminated. The incubation was done at room temperature (23-29 ${ }^{\circ} \mathrm{C}$ ) for $48 \mathrm{hrs}$ to allow the hatching process, and nauplii were collected in the illuminated section.

Different focuses of the crude extract in ocean water were utilized, i.e., 10,100 , and $1,000 \mu \mathrm{g} / \mathrm{mL}$, to test for poisonous quality. A stock solvent of $10,000 \mu \mathrm{g} / \mathrm{mL}$ for every crude extract was made ready. For those aqueous extracts, the stock solvent of $10,000 \mu \mathrm{g} / \mathrm{mL}$ was made ready by dissolving $0.5 \mathrm{~g}$ of the crude extract in $10 \mathrm{ml}$ of ocean water, while for organic extracts, $0.1 \mathrm{~g}$ of each sample was first disintegrated on $1 \%$ DMSO and then diluted using artificial water to $10 \mathrm{ml}$ to aggravate stock solvent.

Ten brine shrimp larvae were drawn from the hatching tank using Pasteur pipettes and placed in each vial. The volume of artificial seawater in each vial containing 10 Brine shrimp salina was expanded to $5 \mathrm{~mL}$ for vials of 10 and $100 \mu \mathrm{g} / \mathrm{mL}$ of the plant extracts, while for 1,000 $\mu \mathrm{g} / \mathrm{mL}$, it was topped to $4.5 \mathrm{~mL}$. Using micropipettes, 0.5 $\mathrm{mL}, 0.05 \mathrm{~mL}$, and $0.005 \mathrm{~mL}$ were exchanged from the stock solution to the vials containing $5 \mathrm{~mL}$ of artificial seawater to make experimental solutions containing 1,000 $\mu \mathrm{g} / \mathrm{mL}, 100 \mu \mathrm{g} / \mathrm{mL}$, and $10 \mu \mathrm{g} / \mathrm{mL}$, respectively (Table 3 ). Control experiments were done using artificial seawater and DMSO for organic extract and artificial seawater only in the case of aqueous extract (Wanyoike et al. 2004). Three replicates for the three serial dilutions of distinctive unrefined extracts and the control were performed. Surviving nauplii were counted after $24 \mathrm{hr}$ using a magnifying glass, and the average mortality at each concentration was determined as it was essential for the estimation of LC50.

\section{Qualitative phytochemical screening of crude extracts}

In order to recognize a few classes of the auxiliary metabolites in these plants, subjective chemical tests were conducted on all the unrefined plant extracts. Identification was based on a characteristic color change of precipitate or foam development. Alkaloids, flavonoids, saponins, tannins, glycosides, quinines, and terpenoids were detected using standard methods (Trease and Evans 2002) (Table 4).

Table 3. Brine shrimp bioassay set up for each plant extract

\begin{tabular}{ccccccc}
\hline & $\begin{array}{c}\text { Volume } \\
\text { of } \\
\text { Vialsartificial } \\
\text { seawater } \\
(\mathbf{m L})\end{array}$ & $\begin{array}{c}\text { No of Volume } \\
\text { Brine of stockConcentration Nature of } \\
\text { shrimpsolution } \\
\text { larvae }\end{array}$ & $\begin{array}{c}\text { (mL) } \\
(\boldsymbol{\mu} \text { g/mL) }\end{array}$ & & $\begin{array}{c}\text { Final } \\
\text { volume } \\
\text { experiment }\end{array}$ & $\begin{array}{c}\text { in the } \\
\text { vial } \\
(\mathbf{m L})\end{array}$ \\
\hline 1 & 4.5 & 10 & 0.5 & 1,000 & Trial & 5 \\
2 & 4.5 & 10 & 0.5 & 1,000 & Repeat & 5 \\
3 & 4.5 & 10 & 0.5 & 1,000 & Repeat & 5 \\
4 & 5 & 10 & 0.05 & 100 & Trial & 5 \\
5 & 5 & 10 & 0.05 & 100 & Repeat & 5 \\
6 & 5 & 10 & 0.05 & 100 & Repeat & 5 \\
7 & 5 & 10 & 0.005 & 10 & Trial & 5 \\
8 & 5 & 10 & 0.005 & 10 & Repeat & 5 \\
9 & 5 & 10 & 0.005 & 10 & Repeat & 5 \\
10 & 5 & 10 & 0 & 0 & Control & 5 \\
11 & 5 & 10 & 0 & 0 & Control & 5 \\
12 & 5 & 10 & 0 & 0 & Control & 5 \\
\hline
\end{tabular}

Table 4. Detection for phytochemicals

\begin{tabular}{|c|c|}
\hline Phytochemical test & Detection \\
\hline $\begin{array}{l}\text { Test for saponins } \\
\text { (Foam test) }\end{array}$ & $\begin{array}{l}\text { 1g of each extract was shaken with distilled water in a test tube for } 15 \mathrm{mins} \text {. Bubbles that persist on warming } \\
\text { were taken as preliminary evidence for the presence of saponins. }\end{array}$ \\
\hline $\begin{array}{l}\text { Test for sterols } \\
\text { (Salkowaski test) }\end{array}$ & $\begin{array}{l}1 \mathrm{~g} \text { of each extract was dissolved in } 2 \mathrm{~mL} \text { of chloroform, and } 2 \mathrm{~mL} \text { of concentrated sulphuric acid was added } \\
\text { from the side of the test tube. The test tube was shaken for a few minutes. The development of red color in } \\
\text { the chloroform layer indicated the presence of sterols. }\end{array}$ \\
\hline $\begin{array}{l}\text { Test for alkaloids } \\
\text { (Dragendorffs' test) }\end{array}$ & $\begin{array}{l}1 \mathrm{~g} \text { of each extract was dissolved in } 5 \mathrm{~mL} \text { of hydrochloric acid }(1.5 \% \mathrm{v} / \mathrm{v}) \text { and permeated. These filtrates } \\
\text { were then used for testing alkaloids. Dragendorffs' reagent was added into } 2 \mathrm{~mL} \text { of filtrate. The formation of } \\
\text { orange-brown precipitate indicated the presence of an alkaloid. }\end{array}$ \\
\hline Test for tannins & $\begin{array}{l}1 \mathrm{~g} \text { of each extract was stirred with } 10 \mathrm{~mL} \text { of distilled water, filtered, and } 1 \mathrm{~mL} \text { of } 5 \% \text { ferric chloride was } \\
\text { added to the filtrate. A blue-black, green, or blue-green precipitate was taken as evidence of the presence of } \\
\text { tannins. }\end{array}$ \\
\hline Test for flavonoids & $\begin{array}{l}\text { In a test tube with } 1 \mathrm{~g} \text { of each extract, a few drops of dilute sodium hydroxide }(\mathrm{NaOH}) \text { were added and } \\
\text { shaken. An intense yellow color was produced in the plant extract, which became colorless on adding a few } \\
\text { drops of dilute acid, indicating the presence of flavonoids. }\end{array}$ \\
\hline Test for quinones & $\begin{array}{l}\left.1 \mathrm{~g} \text { of extract was shaken with } 1 \mathrm{~mL} \text { of concentrated sulphuric acid(} \mathrm{H}_{2} \mathrm{SO} 4\right) \text {. The formation of red color } \\
\text { shows the presence of quinones. }\end{array}$ \\
\hline Test for terpenoids & $\begin{array}{l}5 \mathrm{~g} \text { of each extract was mixed with } 2 \mathrm{~mL} \text { of chloroform. } 3 \mathrm{~mL} \text { of concentrated sulphuric acid }(\mathrm{H} 2 \mathrm{SO} 4) \text { was } \\
\text { added to form a layer. A reddish-brown precipitate coloration at the interface formed indicated the presence } \\
\text { of terpenoids. }\end{array}$ \\
\hline
\end{tabular}




\section{Data analysis}

A statistical program for social sciences (statistical analysis software) was used to do a statistical analysis of antimicrobial activity. ANOVA software was used to determine whether there were significant differences in the mean diameter of inhibition zones in various concentrations. Once the means were different, the Dunnett test was then used for some inhibitory comparisons to determine whether inhibition of different treatments differed from the inhibition induced by positive controls. The significance level used in the analysis was 0.05 . The lethal concentration ( $\left.\mathrm{LC}_{50}\right), 95 \%$ confidence interval of the selected plants was determined using the Finney (1971) computer program.

\section{RESULTS AND DISCUSSION}

\section{Yields of extracts from test plants}

The resulting dry powders were weighed and expressed as percentages. Organic extracts yielded a higher percentage than the water extracts, except for $C$. holstii (Table 5).

\section{Antimicrobial activity of the crude extracts against selected microorganisms}

Antimicrobial activity of the crude extracts on MRSA

Crude extracts of $O$. kirkii and $H$. forskahlii had inhibition zones of $15 \mathrm{~mm}$ at $100 \mathrm{mg} / \mathrm{mL}$ in agar well diffusion and disc diffusion (Figures 1 and 5). At 200 $\mathrm{mg} / \mathrm{mL}$, only organic extracts of the four plants were active against this microbe in both agar well and disk diffusion (Figures 2 and 7). Effective growth inhibition was recorded at higher concentrations of each extract (Figures 3 and 6). Of all the aqueous extracts tested in both agar well and disk diffusion, only active $H$. forskahlii resisted these tested bacteria at concentrations of 100,200 , and $400 \mathrm{mg} / \mathrm{mL}$ (Figure 4). In both agar-well diffusion and disk diffusion, among the tested plant extracts, only organic extracts were active against MRSA at all the concentrations tested (Figures 8 and 9). Inhibition of MRSA growth by various extracts from four selected plants significantly $(\mathrm{P} \leq 0.05)$ differed from one another in both agar well and disc diffusion methods (Table 6). The levels of comparative significance of everything except $H$. forskahlii organic plant extract at the test were all under 0.05. Subsequently, the concentrates had development inhibitions of MRSA, which were fundamentally not quite the same as that of the positive control at $\mathrm{P} \leq 0.05$. In any case, organic extracts of H. forskahlii at $400 \mathrm{mg} / \mathrm{mL}$ demonstrated no critical distinction between the positive control at $\mathrm{P} \geq 0.05$ in both agar well and disk diffusion.

\section{Antimicrobial activity of the crude extracts on $P$. aeruginosa}

H. forskahlii organic extracts had a breadth of $6 \mathrm{~mm}$ in agar disk diffusion at $200 \mathrm{mg} / \mathrm{mL}$ (Figure 10). Organic extracts of $S$. alata demonstrated antibacterial action at 400 $\mathrm{mg} / \mathrm{mL}$ in both agar-well and disc dispersion methods (Figures 11 and 13). Among the fluid extracts tested, only
$O$. kirkii indicated antibacterial activity against this bacterial strain at $400 \mathrm{mg} / \mathrm{ml}$ in the two analyses with an inhibition zone of $10 \mathrm{~mm}$ (Figure 12). Of all the tested extracts, $H$. forskahlii organic extracts had the most remarkable inhibition breadth of $10 \mathrm{~mm}$ in agar well (Figures 14 and 15). Organic extracts of $C$. holstii, and $O$. kirkii were not exertive against this microorganism. Moreover, H. forskahlii organic extracts had an inhibition zone of $5.5 \mathrm{~mm}$ at $400 \mathrm{mg} / \mathrm{mL}$ in agar well dispersion (Figure 14). Development inhibitions of $P$. aeruginosa by the different extracts of the four chosen plants in the two experiments were found to be fundamentally different from each other at $95 \%$ confidence intervals $(\mathrm{P} \leq 0.05)$ (Table 6). The criticalness levels of all the plants compared with the positive control at 400,200, and $100 \mathrm{mg} / \mathrm{mL}$ were all under 0.05 , demonstrating that every one of the extracts had development inhibitions of $P$. aeruginosa, which were significantly different from that of chloramphenicol which was utilized as a positive control.

\section{Antimicrobial activity of the crude extracts on Bacillus cereus}

Only organic extract of $H$. forskahlii indicated antibacterial activity against this Gram-positive bacteria with an inhibition zone of 6 and $7 \mathrm{~mm}$ in disk diffusion at 200 and $400 \mathrm{mg} / \mathrm{mL}$, respectively (Figures 16 and17). In contrast, in agar-well diffusion at similar concentrations, inhibition zone of $4.5 \mathrm{~mm}$ and $5 \mathrm{~mm}$ separately appeared by similar extracts (Figures 18 and 19). The positive control had an inhibition breadth of $19 \mathrm{~mm}$ against this microorganism. All the tested extracts demonstrated no action at $100 \mathrm{mg} / \mathrm{mL}$ in both agar well and disk diffusion methods (Figures 21 and 22). The growth inhibitions of $B$. cereus by the different extracts in the two experiments were fundamentally unique at $(\mathrm{P} \leq 0.05)$ (Table 6). Their criticalness levels of correlation of all the plants with the positive control at coalescence, 400 and $200 \mathrm{ml}$, were all under 0.05 . Consequently, every extract had development inhibitions of $B$. cereus, which were altogether not the same as that of the positive control at $\mathrm{P} \leq 0.05$ in both agar well and disk diffusion methods (Figure 20).

\section{Antimicrobial activity of the crude extracts on E. coli}

Only natural coalescence of $H$. forskahlii was exertive against this Gram-negative bacterial strain at 200 and 400 $\mathrm{mg} / \mathrm{mL}$ in the disc diffusion method (Figures 23 and 24). Also, of all the tested extracts, only natural extracts of $H$. forskahlii were exertive at $400 \mathrm{mg} / \mathrm{mL}$ (Figure 25). Inhibition zones of $6 \mathrm{~mm}$ were noted at $400 \mathrm{mg} / \mathrm{mL}$ in both agar well and disc diffusion method (Figures 26 and 27). Growth inhibition of $E$. coli by the different coalescences of the four chosen plants in the two methods was observed to be essentially different from each other at $95 \%$ certainty intervals $(\mathrm{P} \leq 0.05)$ (Table 6$)$. The criticalness levels of all the plants compared with the positive control at 400, 200, and $100 \mathrm{mg} / \mathrm{mL}$ were all under 0.05 , demonstrating that every extract had growth inhibition of $E$. coli which was significantly different from that of Chloramphenicol which was utilized as a positive control in both agar well and disk diffusion. 
Table 5. Percentage yields of extracted crude plant extracts

\begin{tabular}{|c|c|c|c|c|}
\hline Plant species & Part used & Solvent & Extraction type & $\begin{array}{l}\% \text { yield to weight of the } \\
\text { dry powered plant }\end{array}$ \\
\hline \multirow[t]{2}{*}{ Ormocarpum kirkii } & Aerial part & Water & Freeze drying & 3.79 \\
\hline & & Dichloromethane-methanol (1: 1) & Rotary evaporator & 3.94 \\
\hline \multirow[t]{2}{*}{ Schrebera alata } & Bark & Water & Freeze drying & 9.35 \\
\hline & & Dichloromethane-methanol (1: 1) & Rotary evaporator & 13.23 \\
\hline \multirow[t]{2}{*}{ Cussonia holstii } & Bark & Water & Freeze drying & 4.76 \\
\hline & & Dichloromethane-Methanol (1: 1) & Rotary evaporator & 4.47 \\
\hline \multirow[t]{2}{*}{ Helichrysum forskahlii } & Whole plant & Water & Freeze drying & 6.32 \\
\hline & & Dichloromethane-Methanol (1:1) & Rotary evaporator & 10.74 \\
\hline
\end{tabular}

Note: Percentage yields of crude extract (\% yields) = extracted weights/initial weights x 100 (All weights in grams)

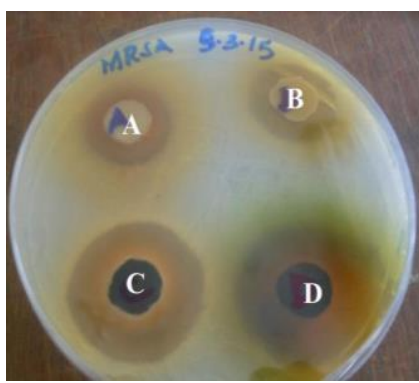

1

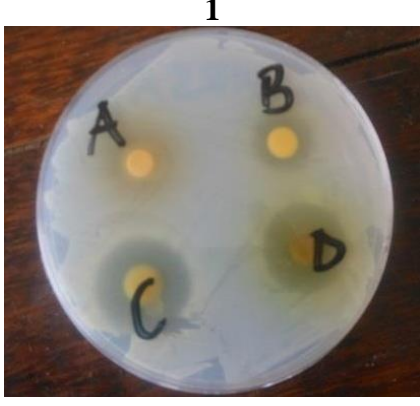

5

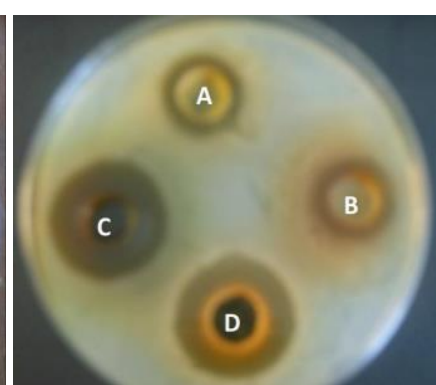

2

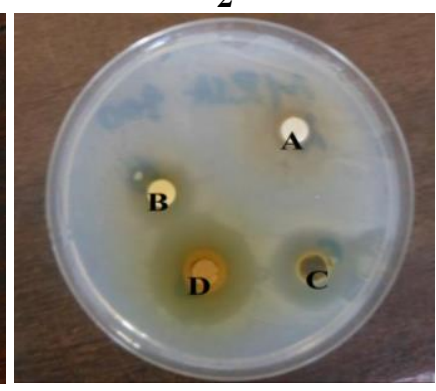

6

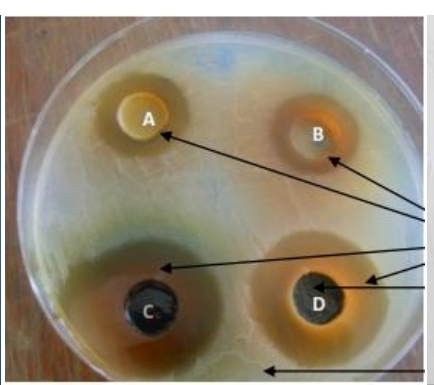

3

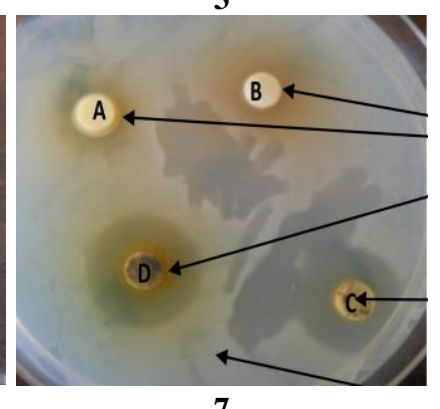

7

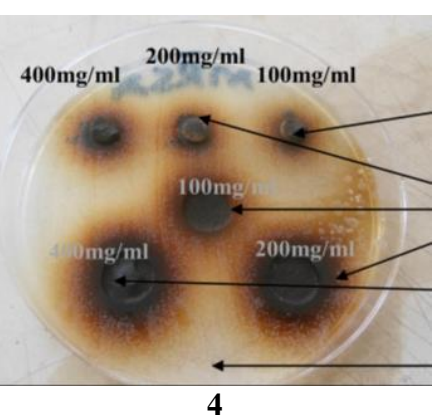

Figure 1. Antibacterial activity of organic extracts $100 \mathrm{mg} / \mathrm{mL}$ in a plate of MRSA in agar well diffusion method. Note for all discplates: A. Organic Cussonia holstii, B. Organic Schrebera alata, C. Organic Ormocarpum kirkii, D. Organic Helichrysum forskahlii, E. Aqueous Cussonia holstii, F. Aqueous Schrebera alata, G. Aqueous Pseudomonas aeruginosa, H. Aqueous Ormocarpum kirkii.

Figure 2. Antibacterial activity of organic extracts $200 \mathrm{mg} / \mathrm{mL}$ in a plate of MRSA in agar well diffusion method

Figure 3. Antibacterial activity of organic extracts $(400 \mathrm{mg} / \mathrm{mL})$ in a plate of MRSA in agar well diffusion method

Figure 4. Antibacterial activity of aqueous extracts of $H$. forskahlii in a plate of MRSA in agar well and disk diffusion method at various concentrations.

Figure 5. Antibacterial activity of organic extracts $(100 \mathrm{mg} / \mathrm{mL})$ in a plate of MRSA in agar disc diffusion method Figure 6. Antibacterial activity of organic extracts $(400 \mathrm{mg} / \mathrm{mL})$ in a plate of MRSA in agar disc diffusion method Figure 7. Antibacterial activity of organic extracts $(200 \mathrm{mg} / \mathrm{mL})$ in a plate of MRSA in agar disc diffusion method
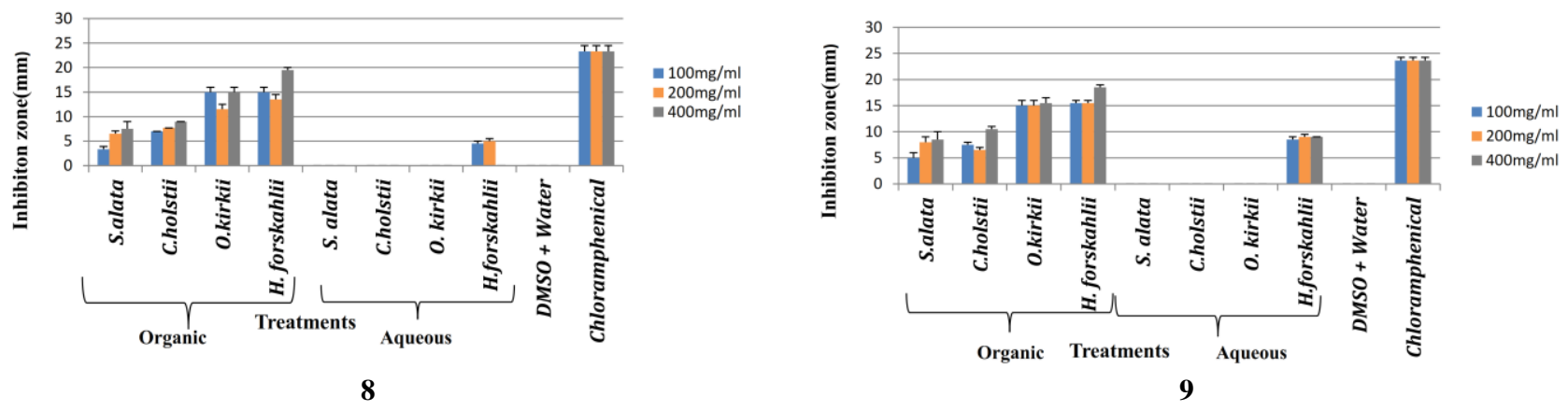

Figure 8. Growth inhibition of the crude extracts on MRSA in agar disc diffusion

Figure 9. Growth inhibition of the crude extracts on MRSA in agar well diffusion 


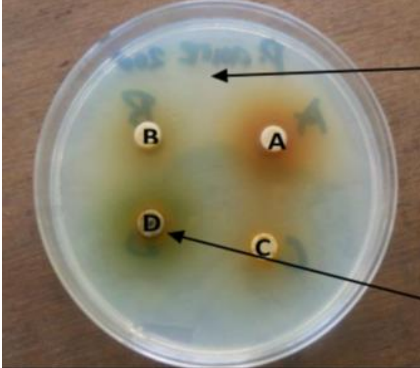

10

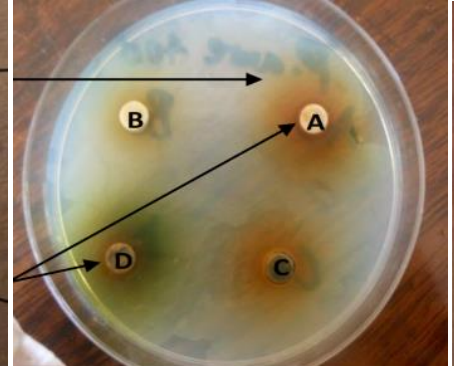

11

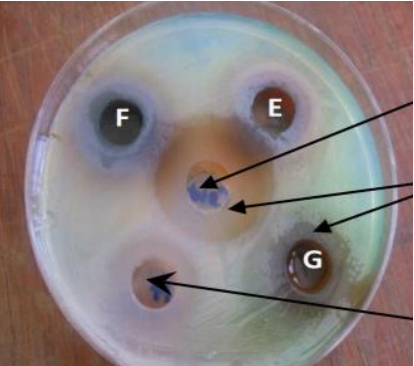

12

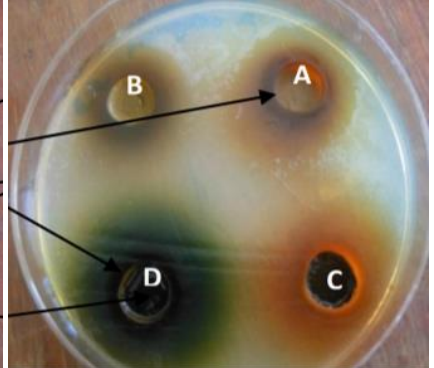

13

Figure 10. Antibacterial activity of organic extracts $(200 \mathrm{mg} / \mathrm{mL})$ in a plate of $P$. aeruginosa in agar disc diffusion method

Figure 11. Antibacterial activity of organic extracts $(400 \mathrm{mg} / \mathrm{mL})$ in a plate of $P$. aeruginosa in agar disc diffusion method Figure 12. Antibacterial activity of aqueous extracts $(400 \mathrm{mg} / \mathrm{mL})$ in a plate of $P$. aeruginosa in agar well diffusion method Figure 13. Antibacterial activity of organic extracts $(400 \mathrm{mg} / \mathrm{mL})$ in a plate of $P$. aeruginosa in agar well diffusion method

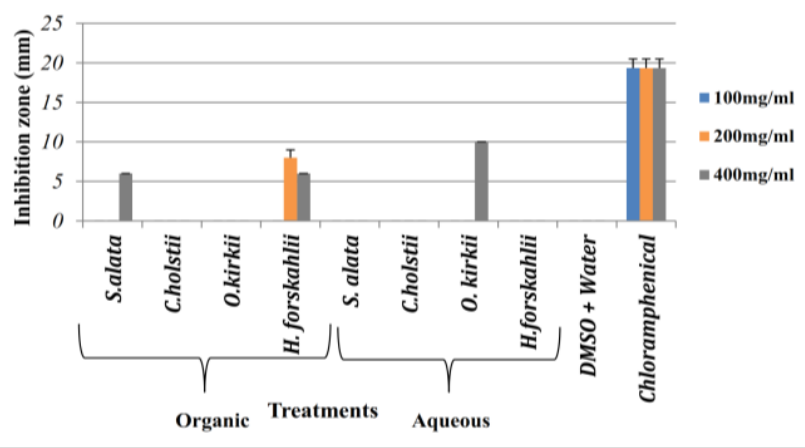

14

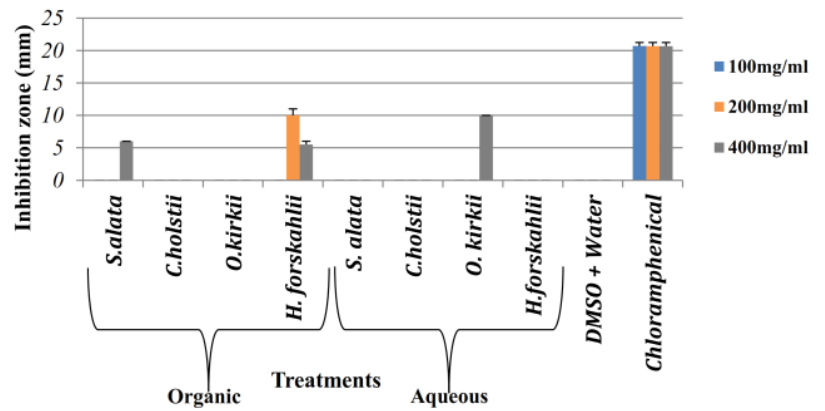

15

Figure 14. Growth inhibition of the crude extracts on $P$. aeruginosa in agar disc diffusion Figure 15. Growth inhibition of the crude extracts on $P$. aeruginosa in agar well diffusion

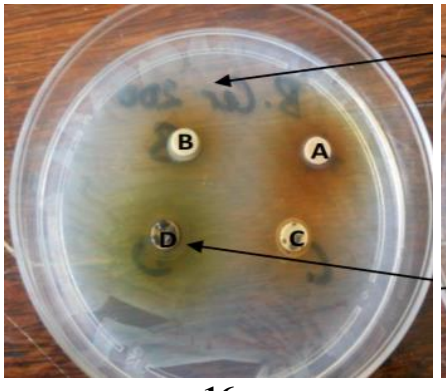

16

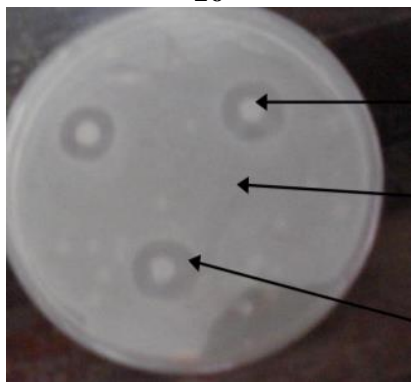

20

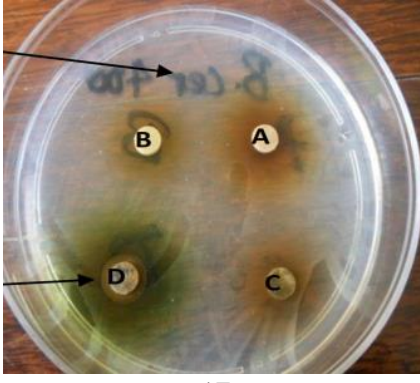

17

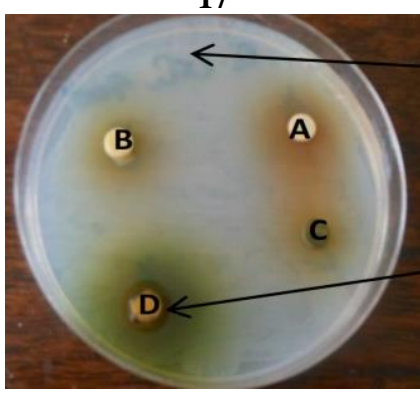

23

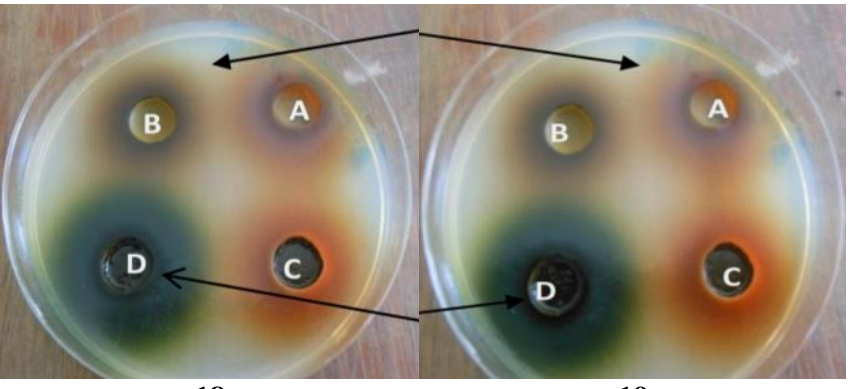

18

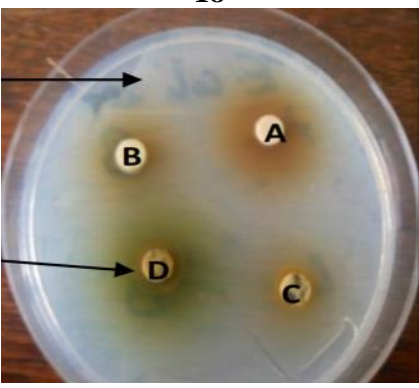

24

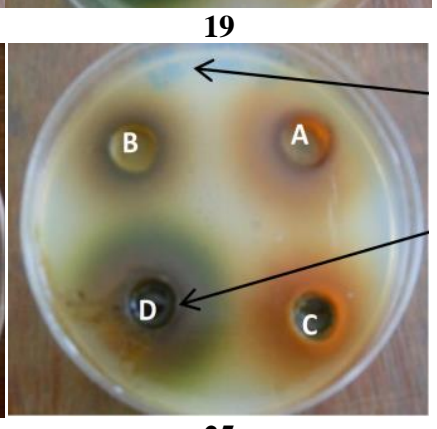

25

Figure 16. Antibacterial activity of organic extracts $D(200 \mathrm{mg} / \mathrm{mL})$ in a plate of B. cereus in agar disk diffusion method Figure 17. Antibacterial activity of organic extracts $D(400 \mathrm{mg} / \mathrm{mL})$ in a plate of $B$. cereus in agar disk diffusion method

Figure 18. Antibacterial activity of organic extracts $D(200 \mathrm{mg} / \mathrm{mL})$ in a plate of $B$. cereus in agar disk diffusion method

Figure 19. Antibacterial activity of organic extracts $D(400 \mathrm{mg} / \mathrm{mL})$ in a plate of $B$. cereus in agar disk diffusion method

Figure 20. Antibacterial activity of chloramphenicol in a plate of B. cereus in agar diffusion method

Figure 23: Antibacterial activity of organic extracts $\mathrm{D}(400 \mathrm{mg} / \mathrm{mL})$ in a plate of $E$. coli in agar disk diffusion method

Figure 24. Antibacterial activity of organic extracts $D(200 \mathrm{mg} / \mathrm{mL})$ in a plate of $E$. coli in agar disk diffusion method

Figure 25. Antibacterial activity of organic extracts $\mathrm{D}(400 \mathrm{mg} / \mathrm{mL})$ in a plate of E. coli in agar well diffusion method 


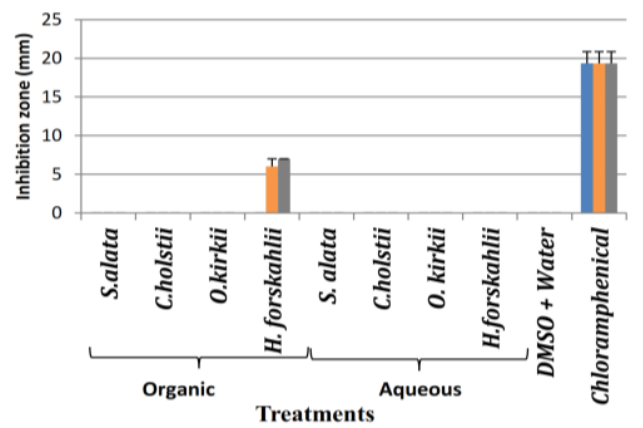

21
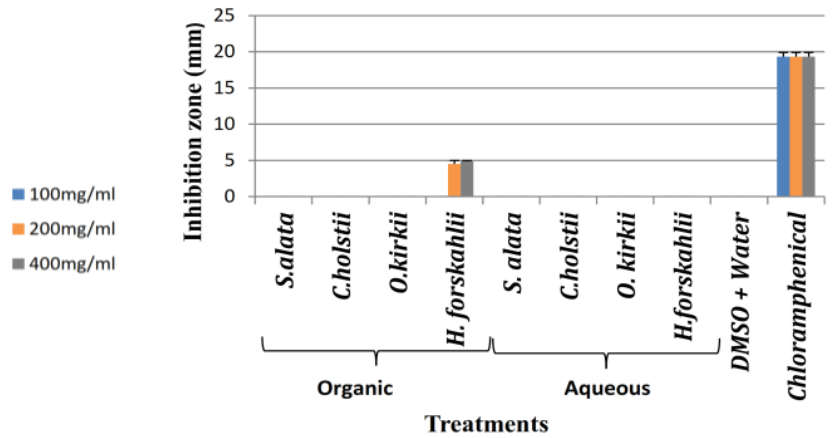

22

Figure 21. Growth inhibition of the crude extracts on B. cereus in disc diffusion

Figure 22. Growth inhibition of the crude extracts on B. cereus in agar well diffusion
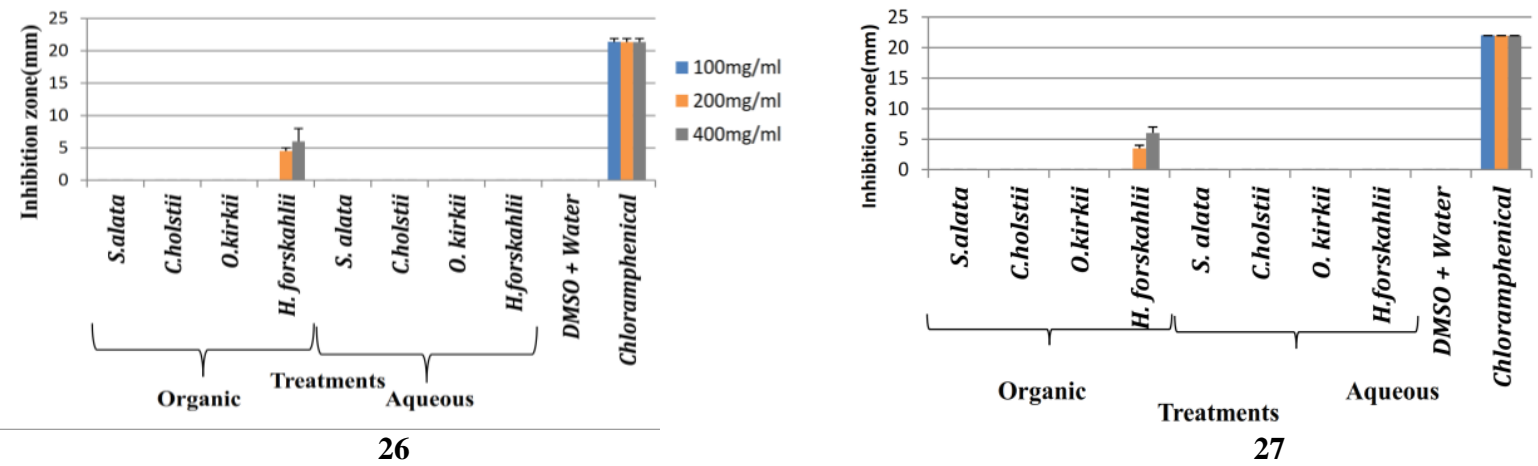

$=100 \mathrm{mg} / \mathrm{m}$

Figure 26. Growth inhibition of the crude extracts against $E$. coli in agar disc diffusion

Figure 27. Growth inhibition of the crude extracts on E. coli in agar well diffusion

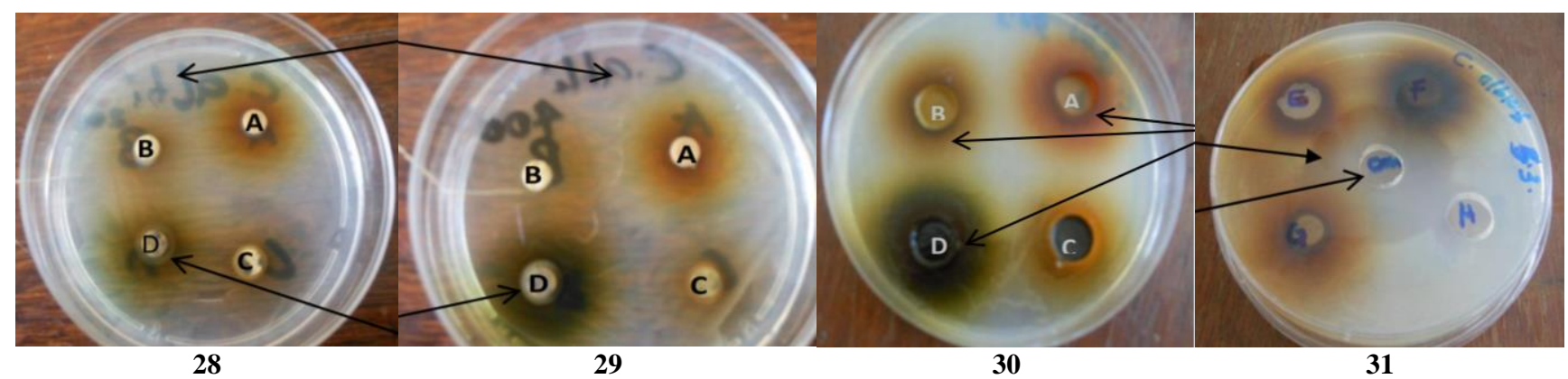

Figure 28. Antibacterial activity of organic extracts $(200 \mathrm{mg} / \mathrm{mL})$ in a plate of C. albicans in agar disc diffusion method

Figure 29. Antibacterial activity of organic extracts $(400 \mathrm{mg} / \mathrm{mL})$ in a plate of C. albicans in agar disc diffusion method

Figure 30. Antibacterial activity of organic extracts $(400 \mathrm{mg} / \mathrm{mL})$ in a plate of $C$. albicans in agar well diffusion method

Figure 31. Antibacterial activity of organic extracts $(400 \mathrm{mg} / \mathrm{mL})$ in a plate of C. albicans in agar well diffusion method
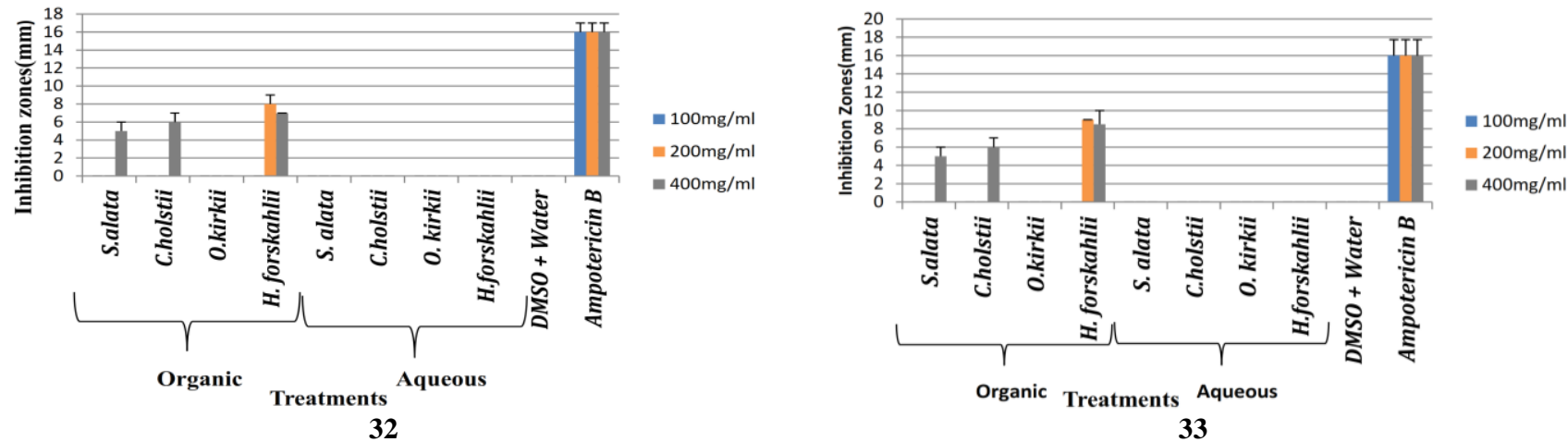

Figure 32. Growth inhibition of the crude extracts on C. albicans in disc diffusion

Figure 33. Growth inhibition of the crude extracts on C. albicans in agar well diffusion 
Antifungal activity of the crude extracts on Candida albicans

In the agar disc method, $H$. forskahlii had antifungal activity at 200 and $400 \mathrm{mg} / \mathrm{mL}$ (Figures 28 and 29). Thus, inhibition zones were noted in organic extracts of $H$. forskahlii at $400 \mathrm{mg} / \mathrm{in}$ agar well diffusion (Figure 30). Amphotericin B (positive control) had an inhibition breadth of $16 \mathrm{~mm}$ against $C$. albicans (Figure 31). Furthermore, at $400 \mathrm{mg} / \mathrm{mL}$, organic extracts of S. alata, C. holstii, were exertive against this fungi strain (Figures 32 and 33). The most elevated antifungal activity with an inhibition zone estimation of $8.5 \mathrm{~mm}$ was seen in organic extracts of $H$. forskahlii in agar well diffusion. It was clear that growth inhibition of C. albicans by different extracts from the four plants was fundamentally different from each other in both experiments. $(\mathrm{P} \leq 0.05)$ (Table 6). Comparison of growth inhibition by all plants with the positive control at 400 , 200, and $100 \mathrm{mg} / \mathrm{mL}$ proved that all the extracts had growth inhibition of $C$. albicans which were fundamentally different from that Amphotericin B utilized as a positive control in both agar well and disc diffusion.

\section{Minimum inhibitory concentration (MIC) of plant extracts against the test microorganism}

Results of least inhibitory focus (MIC) of plant extracts against the test microorganisms appeared in Table 7. MIC values differed with plant specimens from 250 to 15.625 $\mathrm{mg} / \mathrm{mL}$. The MIC values of the test extract additionally shifted against various test pathogens. The outcomes obtained from these examinations uncovered that MRSA was the most-touchy bacteria at the lower MIC value of $15.625 \mathrm{mg} / \mathrm{mL}$ by the biggest number of crude extracts.

\section{Toxicity of the crude plant extracts on brine shrimp larvae}

Each plant's mean lethality in the three concentrations $(1 \mathrm{mg} / \mathrm{mL}, 0.1 \mathrm{mg} / \mathrm{mL}$, and $0.01 \mathrm{mg} / \mathrm{mL})$ were fed into the Finney computer program estimate (LC50) of the crude plant extracts. The results are displayed in Tables 8 and 13 .

Consideration of toxicity was based on Nguta et al. (2011), where LC50 ranging between $0-0.1 \mathrm{mg} / \mathrm{mL}$ indicated high toxicity, LC50 between $0.1-0.5 \mathrm{mg} / \mathrm{mL}$ indicated moderate toxicity, LC50 between $0.5-1 \mathrm{mg} / \mathrm{mL}$ indicated weakly toxicity and LC50 over $1 \mathrm{mg} / \mathrm{mL}$ indicated non-toxic nature of the extract. Aqueous crude plant extracts of $O$. kirkii $(0.412 \mathrm{mg} / \mathrm{mL})$ and $S$. alata $(0.317 \mathrm{mg} / \mathrm{mL})$ were moderately toxic. In contrast, aqueous extract of $C$. holstii $(0.544 \mathrm{mg} / \mathrm{mL})$ had weak toxicity, while aqueous extracts of $H$. forskahlii were non-toxic with LC50 of $1.206 \mathrm{mg} / \mathrm{mL}$. Organic crude extracts of $H$. forskahlii and C. holstii were highly toxic $(0.009 \mathrm{mg} / \mathrm{mL}$. In contrast,e organic extracts of $O$. kirkii $(0.207 \mathrm{mg} / \mathrm{mL})$ and $S$. alata $(0.399 \mathrm{mg} / \mathrm{mL})$ were moderately toxic.

Table 6. MRSA, P. aeruginosa, B. cereus E. coli, and C. albicans inhibition at different concentrations by various extracts

\begin{tabular}{|c|c|c|c|}
\hline \multirow{2}{*}{ Method } & \multicolumn{3}{|c|}{ Concentration in $\mathrm{mg} / \mathrm{mL}$} \\
\hline & 100 & 200 & 400 \\
\hline \multicolumn{4}{|l|}{ MRSA } \\
\hline Disc diffusion & $\begin{array}{c}\mathrm{F}=519.27 \\
\mathrm{P}=0.00\end{array}$ & $\begin{array}{c}F=325.75 \\
P=0.00\end{array}$ & $\begin{array}{c}F=466.22 \\
P=0.00\end{array}$ \\
\hline Agar well diffusion & $\begin{array}{c}F=663.63 \\
P=0.00\end{array}$ & $\begin{array}{c}\mathrm{F}=516.84 \\
\mathrm{P}=0.00\end{array}$ & $\begin{array}{c}\mathrm{F}=469.74 \\
\mathrm{P}=0.00\end{array}$ \\
\hline \multicolumn{4}{|l|}{ P. aeruginosa } \\
\hline Disc diffusion & - & $\begin{array}{l}F=1.07 \\
P=0.00\end{array}$ & $\begin{array}{l}F=2.38 \\
P=0.00\end{array}$ \\
\hline Agar well diffusion & $\begin{array}{l}- \\
-\end{array}$ & $\begin{array}{l}F=1.08 \\
P=0.00\end{array}$ & $\begin{array}{l}F=2.38 \\
P=0.00\end{array}$ \\
\hline \multicolumn{4}{|l|}{ B. cereus } \\
\hline Disc diffusion & $\begin{array}{l}- \\
-\end{array}$ & $\begin{array}{c}\mathrm{F}=345.60 \\
\mathrm{P}=0.00\end{array}$ & $\begin{array}{c}\mathrm{F}=504.91 \\
\mathrm{P}=0.00\end{array}$ \\
\hline Agar well diffusion & $\begin{array}{l}- \\
-\end{array}$ & $\begin{array}{l}F=1.93 \\
P=0.00\end{array}$ & $\begin{array}{l}F=3.40 \\
P=0.00\end{array}$ \\
\hline E. coli & & & \\
\hline Disc diffusion & - & $\begin{array}{l}F=2.33 \\
P=0.00\end{array}$ & $\begin{array}{c}\mathrm{F}=320.31 \\
\mathrm{P}=0.00\end{array}$ \\
\hline Agar well diffusion & $\begin{array}{l}- \\
-\end{array}$ & $\begin{array}{l}F=5.75 \\
P=0.00\end{array}$ & $\begin{array}{l}F=1.47 \\
P=0.00\end{array}$ \\
\hline C. albicans & & & \\
\hline Disc diffusion & - & $\begin{array}{c}\mathrm{F}=437.33 \\
\mathrm{P}=0.00\end{array}$ & $\begin{array}{c}\mathrm{F}=278.22 \\
\mathrm{P}=0.00\end{array}$ \\
\hline Agar well diffusion & - & $\begin{array}{c}F=305.00 \\
P=0.00\end{array}$ & $\begin{array}{c}\mathrm{F}=121.02 \\
\mathrm{P}=0.00\end{array}$ \\
\hline
\end{tabular}

Table 7. Minimum inhibitory concentration (MIC) in $\mathrm{mg} / \mathrm{mL}$

\begin{tabular}{|c|c|c|c|c|c|c|}
\hline Plant & Solvent & E. coli & $P$. aeruginosa & MRSA & B. cereus & C. albicans \\
\hline \multirow[t]{2}{*}{ O. kirkii } & Organic & - & - & 31.25 & - & - \\
\hline & Aqueous & - & 250 & - & - & - \\
\hline \multirow[t]{2}{*}{ S. alata } & Organic & - & 15.625 & 15.625 & & 62.5 \\
\hline & Aqueous & - & - & & - & - \\
\hline \multirow[t]{2}{*}{ C. holstii } & Organic & - & - & 15.625 & - & 62.5 \\
\hline & Aqueous & - & - & - & - & - \\
\hline \multirow[t]{2}{*}{ H. forskahlii } & Organic & 62.5 & 31.25 & 15.625 & 31.25 & 31.25 \\
\hline & Aqueous & - & - & 15.625 & - & - \\
\hline
\end{tabular}


Table 8. Mortality data of aqueous extracts in $\mathrm{mg} / \mathrm{mL}$

\begin{tabular}{llll}
\hline $\begin{array}{l}\text { Aqueous plants } \\
\text { extracts }\end{array}$ & $\begin{array}{l}\text { Concentration } \\
(\mathbf{m g} / \mathbf{m L})\end{array}$ & Mean \pm SD & $\begin{array}{l}\text { LC50 } \\
\mathbf{m g} / \mathbf{m L}\end{array}$ \\
\hline O. kirkii & 0.01 & $1.67 \pm 1.53$ & 0.42 \\
& 0.1 & $4.00 \pm 2.00$ & \\
H. forskahlii & 1 & $9.00 \pm 1.00$ & \\
& 0.01 & 0 & 1.21 \\
& 0.1 & 0 & \\
C. holstii & 1 & $5.67 \pm 1.53$ & \\
& 0.01 & 0 & 0.54 \\
& 0.1 & $1.00 \pm 0.00$ & \\
S. alata & 1 & $9.00 \pm 1.00$ & \\
& 0.01 & 0 & 0.32 \\
& 0.1 & $4.33 \pm 2.08$ & \\
\hline
\end{tabular}

Phytochemical constituents of the crude plant extracts

The plant extracts showed a positive test for the existence of flavonoids, sterols, alkaloids, tannins, quinones, and terpenoids (Figures 35, 36, 37, and Table 10). Saponins existed in all the extracts screened except organic extracts of $H$. forskahlii (Figure 34).

\section{Discussion}

The percentage yield of the plant extracts

The aggregate sum of unrefined extract acquired with the different solvents demonstrates that methanol: DCM (1: 1) was quantitatively better for all plants' extraction than refined water. Organic extracts of $O$. kirkii, S. alata, and $H$. forskahlii had higher yields than aqueous extracts. However, aqueous extracts of $C$. holstii had higher yields than organic extracts of a similar plant. The productivity of methanol in the extraction of phytochemicals has been reported in other studies (Ezekiel et al., 2009). These results appeared to be consistent with others confirming methanol as a decent solvent for extraction of bioactive mixtures from plants as it gave the most elevated yield in the three studied plants. Thus, Dichloromethane extracts were less polar mixtures, while methanol extracts were more polar mixtures.

Antimicrobial activity of plant extracts

In the present study, in vitro antimicrobial activities of four chosen therapeutic plants were evaluated against two Gram-positive bacteria (MRSA, B. cereus), two Gram-
Table 9. Mortality data of organic extracts in $\mathrm{mg} / \mathrm{mL}$

\begin{tabular}{llll}
\hline $\begin{array}{l}\text { Organic plants } \\
\text { extracts }\end{array}$ & $\begin{array}{l}\text { Concentration } \\
(\mathbf{m g} / \mathbf{m L})\end{array}$ & Mean \pm SD & $\begin{array}{l}\text { LC50 } \\
\mathbf{m g} / \mathbf{m L}\end{array}$ \\
\hline O. kirkii & 0.01 & $2.33 \pm 1.53$ & 0.21 \\
& 0.1 & $8.33 \pm 1.53$ & \\
H. forskahlii & 1 & $9.67 \pm 0.58$ & \\
& 0.01 & $10.00 \pm 0.00$ & 0.01 \\
& 0.1 & $10.00 \pm 0.00$ & \\
C. holstii & 1 & $10.00 \pm 0.00$ & \\
& 0.01 & $10.00 \pm 0.00$ & 0.01 \\
& 0.1 & $10.00 \pm 0.00$ & \\
S. alata & 1 & $10.00 \pm 0.00$ & \\
& 0.01 & $3.67 \pm 5.51$ & 0.40 \\
& 0.1 & $2.20 \pm 2.00$ & \\
\hline
\end{tabular}

negative bacteria (E. coli, $P$. aeruginosa), and a fungus ( $C$. albicans) uncovered that they have potential antimicrobial substances against a majority of the tested microorganisms.

The tested plant extracts were more exertive against Gram-positive bacteria compared to Gram-negative. The most sensitive bacterium was MRSA which was hindered by the unrefined organic extracts of all chosen plants. Generally, Gram-negative bacteria are more resistant than Gram-positive bacteria (Nurul et al., 2010; Darah et al., 2011; Nor et al., 2012). The higher affectability of Grampositive bacteria (MRSA) could be because of the introduction of the external peptidoglycan layer (Korir et al. 2012), while Gram-negative bacteria bear an additional outer membrane $(\mathrm{OM})$ which incorporates the lopsided circulation of the lipids with phospholipids and lipopolysaccharide (LPS) situated in the inner and outer leaflets, respectively can act as an extra boundary which inhibits the development of foreign substance into the cell (Pages et al. 2008).

These results of both agar diffusion methods were found not to differ significantly from each other $(\mathrm{P}>0.05)$. This was in concurrence with Parekh and Chanda (2007). More so, the principle of the agar well diffusion is the same as that of the agar disk diffusion method (Ncube et al. 2008).

Table 10. Relative abundance of detected phytochemical in crude plant extracts

\begin{tabular}{|c|c|c|c|c|c|c|c|c|}
\hline Plant & Crude extracts & Sterols & Alkaloids & Saponins & Flavonoids & Tannins & Quinones & Terpenoids \\
\hline \multirow[t]{2}{*}{ O. kirkii } & Organic & ++ & + & + & +++ & + & +++ & +++ \\
\hline & Aqueous & +++ & ++ & ++ & +++ & + & +++ & +++ \\
\hline \multirow[t]{2}{*}{ S. alata } & Organic & +++ & +++ & ++ & +++ & +++ & +++ & +++ \\
\hline & Aqueous & +++ & + & ++ & +++ & ++ & +++ & +++ \\
\hline \multirow[t]{2}{*}{ C. holstii } & Organic & +++ & ++ & +++ & +++ & +++ & ++ & +++ \\
\hline & Aqueous & +++ & + & + & +++ & + & +++ & + \\
\hline \multirow[t]{2}{*}{ H. forskahlii } & Organic & +++ & ++ & - & +++ & + & ++ & +++ \\
\hline & Aqueous & +++ & ++ & +++ & +++ & +++ & +++ & ++ \\
\hline
\end{tabular}

Note: +++ : strong presence, ++ : moderate presence, + weak presence,-: not detected 

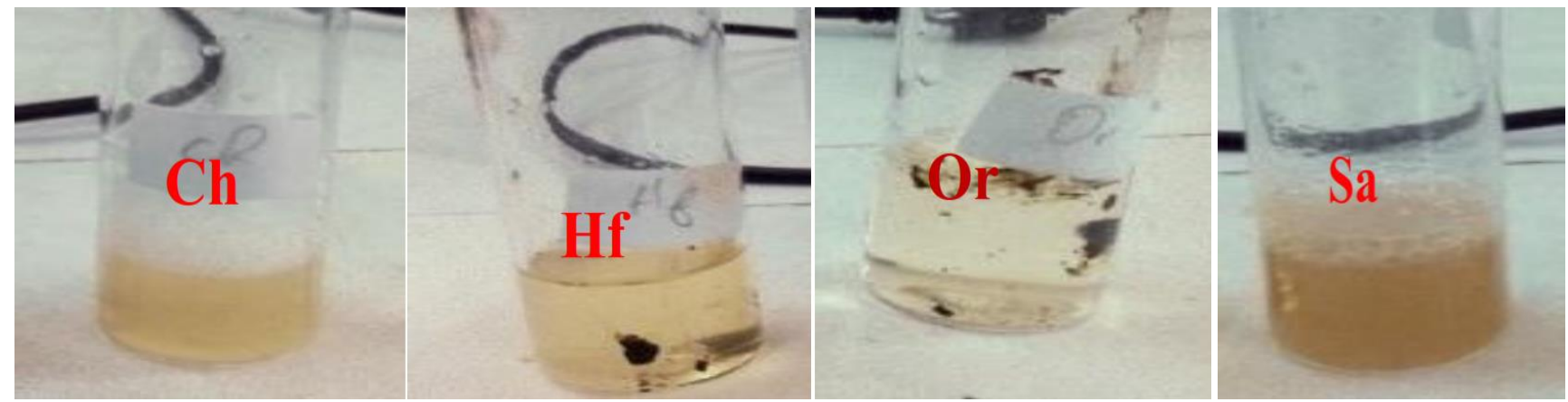

Figure 34. A photograph shows the existence of saponins in organic extracts. Sa indicates the moderate presence of saponins, Ch: organic Cussonia holstii Sa: organic, Schrebera alata Or: organic Ormocarpum kirkii Hf: organic Helichrysum forskahlii

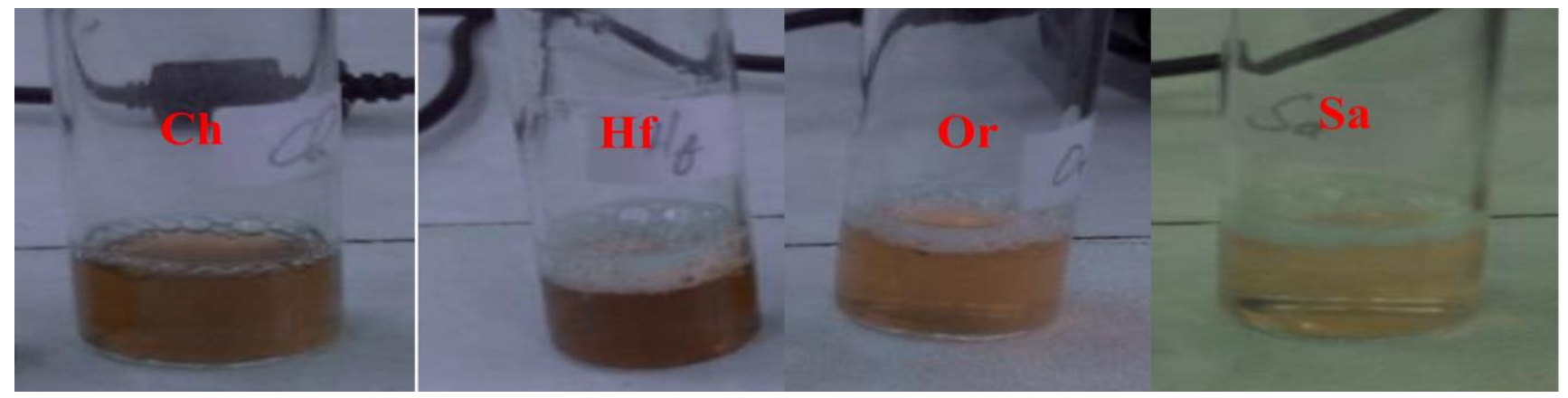

Figure 35. A photograph shows the existence of saponins in aqueous extracts. Ch: aqueous Cussonia holstii, Sa: aqueous Schrebera alata, Or: aqueous Ormocarpum kirkii, Hf: aqueous Helichrysum forskahlii, Hf indicates a strong presence of saponins

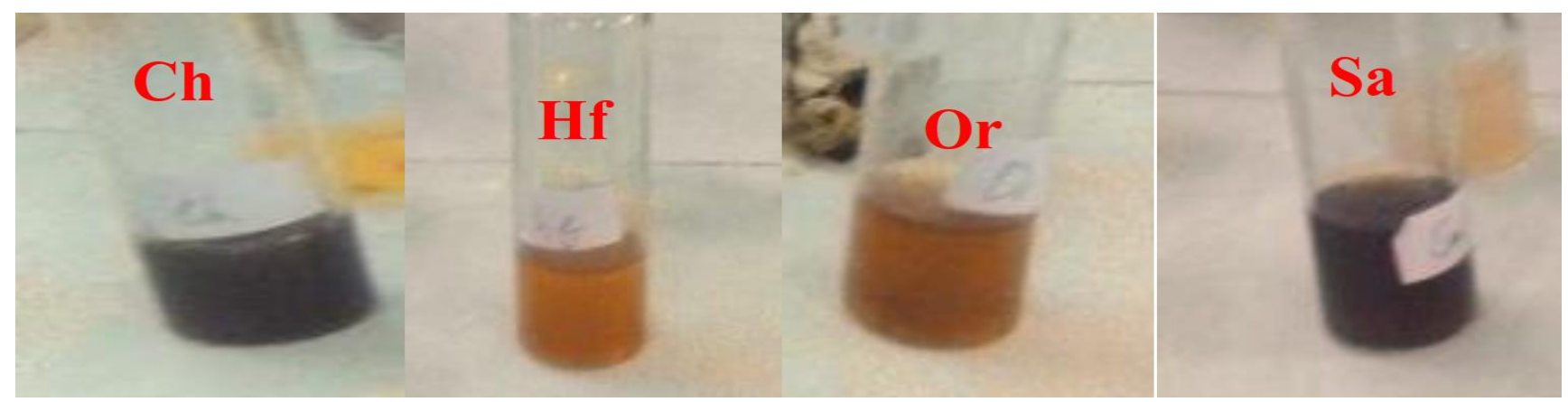

Figure 36. A photograph shows the existence of tannin in the organic extract. Ch: organic Cussonia holstii, Sa: organic Schrebera alata, Or: organic Ormocarpum kirkii, Hf: organic Helichrysum forskahlii. The dark green /deep blue in Ch and Sa indicates a strong presence of tannins.

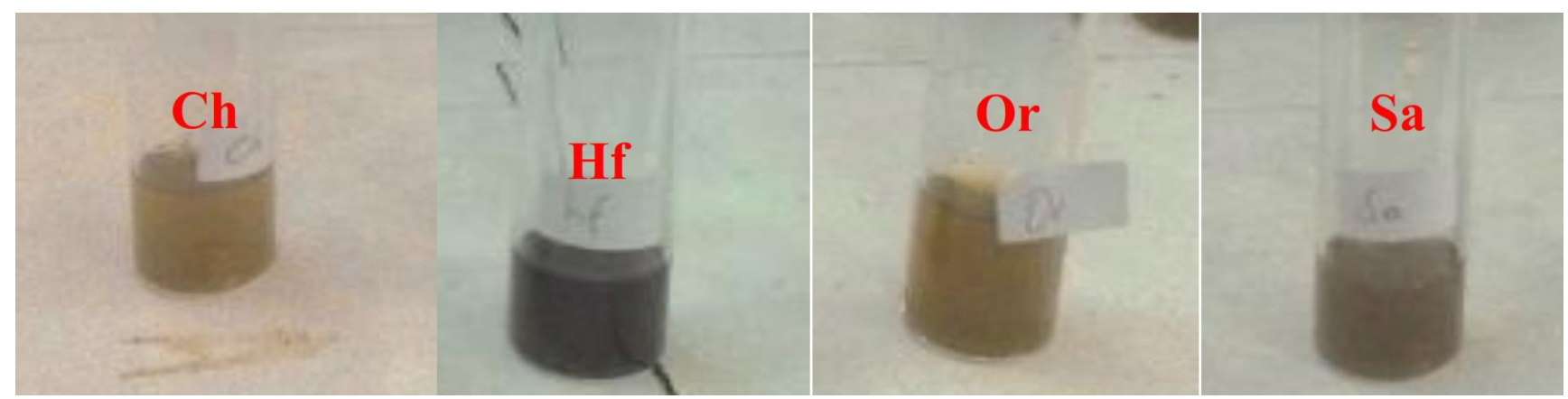

Figure 37. A photograph shows the existence of tannin in aqueous extracts. Ch: aqueous Cussonia holstii, Sa: aqueous Schrebera alata, Or: aqueous Ormocarpum kirkii, Hf: aqueous Helichrysum forskahlii. The dark green /deep blue in Hf indicates a strong presence of tannins. 


\section{Antibacterial activity of organic plant extracts}

From this examination, it is clear the dichloromethane: methanol (1: 1) solvent extracts of all tested plants were more potent than their relating aqueous extracts against all the tested microbes. This examination is quite compelling, given that, traditionally, the preparation of herbal remedies is often with water. This might have resulted from the lower solubility of the active constituents in the aqueous solution. Cowan (1999) demonstrated that aqueous extraction could be ineffective because water-soluble compounds might interrupt the antimicrobial effect. In addition, antimicrobial phytochemicals are soluble in moderately polar solvents. Clarkson et al. (2004) clarified that the inactivity of water extracts may have been because they (extracts) were not prepared according to the traditional methods, which in some cases involved boiling for several hours. All tested organic plant extracts showed antibacterial activity against most bacteria employed in this study. Among the tested plant extracts, only organic extract from $H$. forskahlii at $400 \mathrm{mg} / \mathrm{mL}$ against MRSA had similar activity as the positive control $(\mathrm{P}>0.05)$. Investigation in this study also revealed that the sampled plants differ in their activities against the tested pathogens. The results also clearly showed that antibacterial activity varied with the species of the plant and the solvents used for extraction. In addition, all extracts exhibited concentration-dependent activity at tested concentrations; higher activity was observed at high concentrations (400 $\mathrm{mg} / \mathrm{mL}$ ) in both agar well and disk diffusion method. Organic extracts of $H$. forskahlii showed significant antimicrobial activity against the tested pathogenic organisms. The antibacterial activity of $H$. forskahlii demonstrated a broad spectrum compared to other sampled plants. It justified its use in treating various diseases such as stomach and diarrhea (Kajangwe et al. 2008). The largest inhibition zones of extracts of the tested plant were recorded in agar well $(19.5 \mathrm{~mm})$ and disk diffusion $(18.5$ $\mathrm{mm}$ ) by organic extract of this plant at $400 \mathrm{mg} / \mathrm{mL}$. More so, only the above diameters had no significant difference in activity as Chloramphenicol $(\mathrm{P}>0.05)$. Noteworthy inhibition diameters were shown against B. cereus, E. coli, and $P$. aeruginosa at 200 and $400 \mathrm{mg} / \mathrm{mL}$ by organic extracts of the same plant. $H$. forskahlii organic extracts showed antibacterial activity against all tested microorganisms. This antibacterial activity of $H$. forskahlii agrees with Kajangwe et al. (2008) and Al-Rehaily et al. (2008). In the present study, the organic crude extracts of $S$. alata showed inhibitory activity against MRSA and $P$. aeruginosa. Against MRSA, $S$. alata recorded an inhibition zone at 100,200 , and $400 \mathrm{mg} / \mathrm{mL}$ in both agar well and disk diffusion. Organic extracts of $S$. alata showed antibacterial activity only at $400 \mathrm{mg} / \mathrm{mL}$ against $P$. aeruginosa. The sensitivity of $S$. alata to MRSA and $P$. aeruginosa showed activity similar to another species of the same genus Schrebera swietenioides powdered leaf extracts, which exhibited potent inhibitory activity against S. aureus (Mahida and Mohan 2007; Niranjan et al. 2010). More so, Nanyingi et al. (2008) report the use of this plant in Samburu for candidiasis and toothache. Organic extracts of $C$. holstii were active against MRSA in both agar well and disc diffusion methods. The antibacterial activity of this plant against MRSA was observed at all the tested concentrations. The highest antibacterial inhibition activity $(10 \mathrm{~mm})$ was shown in agar well diffusion at $400 \mathrm{mg} / \mathrm{mL}$. This may explain why Cussonia species are used in African traditional medicine for several diseases such as pain, inflammation, traditional management of ear, nose, and throat (ENT) diseases, gastrointestinal problems, malaria, and sexually transmitted diseases (Njoroge and Bussmann 2007), De Villiers et al. 2010). However, this study did not agree with other members of the same genus $C$. spicata, $C$. paniculata, and $C$. arborea methanolic extracts, which show activity against $E$. coli and $P$. aeruginosa (De Villiers et al. 2010). The organic extracts of $O$. kirkii were only active against MRSA. This is in line with another species of the same genus, Ormocarpum trichocarpum, which showed antibacterial activity (Chukwujekwu et al., 2013; Pazhanisamy and Ebenezer, 2013).

\section{Antibacterial activity of aqueous plant extracts}

Aqueous extracts of $S$. alata and $C$. holstii had no antimicrobial activity against all the tested microbes. In contrast, aqueous extracts of $H$. forskahlii had activity in all concentrations of $100,200,400 \mathrm{mg} / \mathrm{mL}$ in both agar well and disc diffusion. This observation agrees with Kajangwe et al. (2008); Al-Rehaily et al. (2008), showing this plant is a potential antimicrobial source. Aqueous extracts of $O$. kirkii were active against only Gram-negative bacteria, $P$. aeruginosa. This was in line with another species of the same genus, $O$. trichocarpum, which showed antibacterial activity (Chukwujekwu et al., 2013, Pazhanisamy et al., 2013).

\section{Antifungal activity of plant extracts}

The antifungal activity also varied with the species of the plant and the solvents used for extraction. In addition, all the tested extracts exhibited concentration-dependent activity at tested concentrations; higher activity was observed at high concentrations $(400 \mathrm{mg} / \mathrm{mL})$ in both agar well and disk diffusion methods. C. albicans was not sensitive to any aqueous extract but showed antifungal activity in organic extracts of S. alata, C. holstii, and $H$. forskahlii.

The highest antifungal activity with an inhibition zone value of $8.5 \mathrm{~mm}$ was observed in organic extracts of $H$. forskahlii in agar well diffusion at $400 \mathrm{mg} / \mathrm{mL}$ with a MIC value of $31.25 \mathrm{mg} / \mathrm{mL}$. This study was in agreement with another member of the same species, $H$. italicum essential oil, which shows demelanizing activity against Aspergillus niger (Milos et al. 2014). Among the C. holstii extracts tested for antifungal activity, only the organic extracts were active against $C$. albicans in both agar well and disc diffusion methods with a MIC of $62.5 \mathrm{mg} / \mathrm{mL}$. This is in agreement with another member of the same genus, $C$. bancoensis, which reports the antifungal activity of methanol, ethyl acetate, and petroleum ether extracts of the stem bark against the same microorganism and minimum inhibitory concentrations ranging from $0.625 \mathrm{mg} / \mathrm{mL}$ to 2.5 $\mathrm{mg} / \mathrm{mL}$ (Mireku et al. 2014). Njoroge and Bussman (2007) argue that $C$. holstii is used for the traditional management 
of ear, nose, and throat (ENT) diseases in central Kenya. $O$. kirkii extracts had no antifungal activity, which was against Maregesi et al. (2008), which shows hexane root extracts of $O$. kirkii against $C$. albicans had a MIC of $1 \mathrm{mg} / \mathrm{mL}$. Antifungal activity of Schrebera alata was reported for the first time in this study, though, in Samburu, studies show that the root and bark of this plant are pounded or chewed as a treatment for candidiasis and toothache (Nanyingi et al. 2008).

\section{Minimum Inhibitory Concentration}

Interestingly, MIC values of less than $100 \mathrm{mg} / \mathrm{mL}$ were observed in broth micro dilutions but not an AST, and this could be due to the microdilution method providing a potentially useful technique for determining MICs increased sensitivity for small quantities of extracts which is important if the antimicrobial is scarce as is the case for many natural products (Ncube et al. 2008). More so, dilution testing methods may be quantitative (MIC), in addition to qualitative (susceptible, intermediate, and resistant), whereas disk methods are only qualitative method (Miller 2005)

Organic and water $\mathrm{H}$. forskahlii extracts were more active against MRSA at lower concentrations, as shown by the MIC value of $15.625 \mathrm{mg} / \mathrm{mL}$ compared to other test microbes. However, Kajangwe et al. (2008) showed the essential oil from $H$. forskahlii presents activity against $E$. coli (MIC between 0.2 and $0.8 \mathrm{mg} / \mathrm{mL}$ ), which varied with the study MIC value $(62.5 \mathrm{mg} / \mathrm{mL})$ against the same bacterium strain. $S$. alata recorded a MIC value of 15.625 $\mathrm{mg} / \mathrm{mL}$ against $P$. aeruginosa and MRSA, which was in line with another member of the same genus, $S$. swietenioides, against S. aureus (Mahida and Mohan 2007). The activity of $C$. holstii against the MRSA recorded a MIC value of 15.625 was in line with De Villiers et al. (2010) and Mireku et al. (2014) that some other species of the same genus against $E$. coli and $P$. aeruginosa. MIC value $(31.25 \mathrm{mg} / \mathrm{mL})$ was revealed by organic extracts of O. kirkii against MRSA in line with Maragesi et al. (2008). However, the lack of antibacterial activity showed by the same plant against $B$. cereus from this study did not agree with Maregesi et al. (2008) earlier report on $\mathrm{MeOH}$ and nHexane root extracts of the same species exhibited antibacterial activity against this microorganism at 0.625 and $0.250 \mathrm{mg} / \mathrm{mL}$.

\section{Brimp shrimp test}

Aqueous extracts of $H$. forskahlii were exertive against MRSA and displayed a non-toxic impact on brine shrimps with $\mathrm{LC}_{50}$ of $1.207 \mathrm{mg} / \mathrm{mL}$. This helps inherent selectivity of the plant extracts for the currency of bacterial illnesses. Outstandingly, aqueous extracts, in most cases, are the ones utilized by traditional practitioners. Consequently, the coalescence of this plant's crude extract at the employed concentration was sheltered, thus legitimizing the continued utilization in customary pharmaceuticals.

McLaughlin et al. (1998) quoted that a plant with less toxicity and equivalently good coalescence of exertive phytochemicals makes it a good plant for use in customary pharmaceuticals compared to one with high toxicity and less toxicity coalescence of exertive phytochemicals.

The middling toxic impact of $O$. kirkii extracts was observed, namely, on aqueous crude plant extracts, it was $0.411 \mathrm{mg} / \mathrm{mL}$, while organic extracts were $0.207 \mathrm{mg} / \mathrm{mL}$. This study reports for the first time the toxicity of this plant. However, it is not in accordance with another member of the same genus, Ormocarpum trichocarpum $(0.072 \mathrm{mg} / \mathrm{mL})$, which is poisonous (Moshi et al. 2006). Mbaya (1976) reported that the bark of $S$. alata has some toxicity because of its impact on the liver. Mbaya's results concur with the results of this study which demonstrates the middling toxicity of inorganic extract of $S$. alata $(0.399$ $\mathrm{mg} / \mathrm{mL})$ and aqueous extract of $S$. alata $(0.317 \mathrm{mg} / \mathrm{mL})$. C. holstii organic extracts uncovered high toxicity (0.009 $\mathrm{mg} / \mathrm{mL}$ ). This was similar to Adepado et al. (2008) on Cussonia paniculata, a member of the same genus, which showed that the plant had caused $80 \%$ mortality in rats. However, the fluid extracts of this plant showed weak toxicity quality $(0.543 \mathrm{mg} / \mathrm{mL})$. Extracts of the plants from organic solvents could have shown higher toxicity because the trace amounts of the solvents are still in them. Practically, it needs thorough "washing" to remove the solvents.

\section{Phytochemical vetting}

Phytochemical vetting of bioactive constituents demonstrated that the extracts were rich in auxiliary metabolites. All plant extracts exhibited nearness of flavonoids, sterols, alkaloids, tannins, quinones, and terpenoids. This study's higher number of phytochemicals in organic extracts most likely clarified their comparatively better antimicrobial potential. Phytochemical vetting of extracts of $H$. forskahlii uncovered the existence of flavonoid sterols, alkaloids, tannins, quinones, and terpenoids in both water and aqueous extracts, while saponins were missing in organic and extracts of this plant. Flavonoids and terpenoids phytoconstituents in the stem bark of $H$. forskahlii had been recorded before (Al-Rehaily et al. 2008; Kajangwe et al. 2008).

Even though $O$. kirkii had low antimicrobial activity, it was wealthier in secondary metabolites, such as flavonoids, alkaloids, tannins, quinones, and terpenoids saponins in all the extracts. From $O$. kirkii, other observers have detached a series of known flavonoids and biflavonoids, as well as chamaejasmin, biliquiritigenin, and isovitexin naringenin (Dhoogle et al. 2010; Xu et al. 2011). A phytochemical examination of $C$. holstii uncovered the existence of saponins, flavonoids, alkaloids, tannins, quinones, and terpenoids. Pentacyclic triterpenoid, i.e., hederagenin, has been archived for its antitrichomonas action (He et al. 2003). S. alata extracts displayed flavonoids, alkaloids, tannins, quinones, and terpenoid saponins in all extracts. The phytochemicals of this plant were first recorded in this study. Nevertheless, the existence of antibacterial alkaloids in another member of the same genus, Schrebera swietenioides by Niranjan et al. 2010 concurs with this study. The existence of secondary metabolites in this plant may attribute to the recognized biological activity (Odhiambo et al., 2014). Flavonoids, saponins, tannins, and 
terpenoids have been reported to have antimicrobial activity and are currently utilized for cough and diarrhea (Talib and Mahasneh, 2010; Khan et al., 2012). Cytotoxicity, antiviral and antimicrobial activities of alkaloids and flavonoids have also been accounted for (Ozcelik et al. 2011). Antibacterial activity and cytotoxic impacts of steroids have been recorded in their usage as arrow poisons (Doughari 2006). The existence of antibacterial substances in higher plants are well entrenched (Bhalodia and Shukla 2011). Plants have given a source of inspiration for novel medication mixtures as plants derived medicines have made a huge contribution to human health.

In conclusion, the bioactivity of organic and aqueous extracts of S. alata, O. kirkii, $C$. holstii, and H. forskahlii against bacterial and fungal strains is critical, with only organic extracts of $H$. forskahlii displaying the most elevated antimicrobial activity similar to a positive control (Chloramphenicol) against MRSA. Generally, flavonoids, sterols, alkaloids, tannins, quinones, and terpenoids were available in all four plant species and tested positive for saponins content except for organic extracts of $H$. forskahlii, which is a lack saponin. Organic crude extracts of $H$. forskahlii and $C$. holstii were found to be highly toxic $(0.009 \mathrm{mg} / \mathrm{mL})$. The study also shows that only aqueous extracts of $\mathrm{H}$. forskahlii of the evaluated crude extracts were non-toxic to Artemia salina, ascertaining value to the selected medicinal plant for continued use in ethnomedicine. Among the studied plant extracts, methanol extracts of $H$. forskahlii had overriding toxicity over other plant extracts. From this study, H. forskahlii is a better source of antimicrobial agents. Hence, it can be mainly of interest in developing new chemotherapeutic drugs. For the first time, this study reports an antimicrobial activity and toxicity of Schrebera alata and Cussonia holstii.

\section{REFERENCES}

Adedapo AA, Sofidiya OM, Maphosa V, Moyo B, Masika JP, Afolayan JA. 2008. Anti-inflammatory and analgesic activities of the aqueous extract of Cussonia paniculata stem Bark. Rec Nat Prod 2: 46-53.

Adenisa SK, Idowu O, Ogundaini AO, Oladimeji H, Olugbade TA, Onawunmi GO, Pais M. 2000. Antimicrobial constituents of the leaves of Acalypha wilkesiana and Acalypha hispida. J Phytother 14: 371-374.

Agnew ADQ, Agnew S. 1994. Upland Kenya flowers. A flora of the ferns and herbaceous flowering plants of Upland Kenya second edition. East African Natural History Society, Nairobi, Kenya.

Al-Rehaily AJ, Albishi OA, El-Olemy MM, Mossa JS. 2008. Flavonoids and ter-penoids from Helichrysum forskahlii. Phytochemistry 69: 1910-1914.

Bauer AW, Kirby MMW, Sherris C J, Turck M. 1966. Antibiotic susceptibility testing by a standardized single disk method. Am. J Clin Pathol 45: 493-496.

Bhalodia NR, Shukla VJ. 2011. Antibacterial and antifungal activities from leaf extract of Cassia fistula, an ethnomedicinal plant. J Adv Pharmaceut Technol Res 2: 104-109.

Chukwujekwu JC, Amoo SO, Staden VJ. 2013. Antimicrobial, antioxidant, mutagenic, and antimutagenic activities of Distephanus angulifolius and Ormocarpum trichocarpum. J Ethnopharmacol 148: 975-979.

Clarkson C, Maharaj VJ, Crouch NR, Olwen M, Grace OM, Pillay P, Matsabisa MG, Bhagwandin N, Smith PJ, Folb PI. 2004. In vitro antiplasmodial activity of medicinal plants native to or naturalized in South Africa. J Ethnopharmacol 92: 177-191.
CLSI [Clinical and Laboratory Standards Institute]. 2008. Reference method for broth dilution antifungal susceptibility testing of yeasts: Approved Standard M27-A3, NCCLS, Wayne, PA.

CLSI [Clinical and Laboratory Standards Institute]. 2009. Methods for dilution antimicrobial susceptibility tests for bacteria that grow aerobically: Approved Standard, eighth ed. M07-A8. CLSI, Wayne, PA.

Cowan M. 1999. Plant products as antimicrobial agents. Clin Microbiol 12: $564-582$.

Cragg GM, Newman DJ. 2005. Plants as a source of anti-cancer agents. J Ethnopharmacol 100: 72-79.

Darah I, Lim CL, Nurul AZ, Nor AS, Shaida FS. 2011. Effects of methanol extract of a soft sponge, sp. on bacterial cells: Structural degeneration study. Pharm Glob Int J Compr Pharm 2: 16-19.

De Villiers BJ, Van Vuuren SF, Van Zyl RL, Van Wyk BE. 2010. Antimicrobial and antimalarial activity of Cussonia species (Araliaceae). J Ethnopharmacol 129: 189-196.

Dhooghe L, Maregesi S, Mincheva I, Ferreira D, Marais J, Lemière F, Matheeusen A, Cos P, Maes L, Vlietinck A, Apers S, Pieters L. 2010. Antiplasmodial activity of (I-3, II-3)-biflavonoids from Ormocarpum kirkii. Phytochemistry 71: 785-791.

Doughari JH. 2006. Antimicrobial activity of Tamarindus indica Linn. Tropical J Pharmaceut Res 5: 597-603.

Ezekiel CN, Anokwuru CP, Nsofor E, Odusanya OA, Adebanjo O. 2009. Antimicrobial activity of the methanolic and crude alkaloid extracts of Acalypha wilkesiana cv. macafeeana copper leaf. Res J Microbiol 4: 269-277.

Ferraro MJ. 2003. Performance Standards for Antimicrobial Disk Susceptibility Tests: Approved Standard. 8th edn, National Committee for Clinical Laboratory Standards (NCCLS), Wayne, PA, USA.

Finney DJ. 1971. Probit analysis, 3rd ed, Cambridge University press., Geissler, P.W,

He W, Van Puyvelde L, Maes L, Bosselaers J, De Kimpe N. 2003. Antitrichomonas in vitro activity of Cussonia holstii Engl. Nat Prod Res 17: 127-133.

Kajangwe V, Tomani J C, Mukazayire M J, Chalchat J C, Duez P. 2008. Chemical composition and antibacterial activity of essential oils of 3 Helichrysum species. In 7th Joint meeting of AFERP, GA, PSE \& SIF (Natural products with pharmaceutical, nutraceutical, cosmetic and agrochemical interest), pp-74: 117.

Kalita D, Saikia J, Devasarmah HK. 2012. Ethonomedicinal, Antibacterial, and Antifungal potentiality of Centella asiatica, Nerium indicum, and Cuscuta reflexa widely used in Tiwa Tribe of Morigaon district of Assam, India. Intl J Phytomed 4: 380-385.

Karehed J, Oduhult E. 1997. An ethnobotanical study among the Maasai of Loita hills, Kenya; Minor field studies No.14, Uppsala.

Khan H, Saeed M, Muhammad N. 2012. Pharmacological and phytochemical updates of genus Polygonatum. Phytopharmacology 3: 286-308.

Kigen KG, Hillary KR, Wilson KK, Joseph KR. 2013. Current trends of Traditional Herbal Medicine Practice in Kenya: A review. African J Pharmacol Therapeut 2: 32-37.

Kitonde CK, Dossaji SF, Lukhoba, CW, Jumba MM. 2013. Antimicrobial activity and phytochemical study of Vernonia glabra (steetz) Oliv. \& Hiern. in Kenya. African J Trad Compl Altern Med 10: 149-157.

Kokwaro JO. 2009. Medicinal plants of East Africa (3rd ed.). University of Nairobi Press, Nairobi.

Kone WM, Kamanzi AK, Terreaux C, Hostettmann K, Traore, D, Dosso M. 2004. Traditional medicine in North Cote-d'Ivoire screening of 50 medicinal plants for antibacterial activity. J Ethnopharmacol 93: 4349.

Korir RK, Mutai C, Kiiyukia C, Bii C. 2012. Antimicrobial Activity and Safety of two Medicinal Plants traditionally used in Bomet District of Kenya. Res J Med Plant 6: 370-382.

Mahida Y, Mohan SSJ. 2007) Screening of plants for their potential antibacterial activity against Staphylococcus and Salmonella spp. Nat Prod Rad 6: 301-305

Maregesi MS, Pieters L, Ngassapa DO, Apers S, Vingerhoets R, Cos P, Vanden Berghe AD, Vlietinck JA. 2008. Screening of some Tanzanian medicinal plants from Bunda district for antibacterial, antifungal, and antiviral activities. J Ethnopharmacol 119: 58-66.

Mbaya BV. 1976. Hepatic changes induced by Schrebera alata, a preliminary report on the toxicology of il kau kawa. African J Medicine Medical Sci 5: 131-137 
McLaughlin JL, Lingling LR, Anderson J E. 1998. The use of biological assays to evaluate botanicals. Drug Inform J 32: 513-524.

Michael JP, Chan EC, Noel RK, Merna FP. 2003. Microbiology. 5th edn, Tata McGraw-Hill, New Delhi, India.

Miller AR. 2005. Development of standardized antimicrobial susceptibility testing methods and Aeromonas salmonicida epidemiologic cutoff values for antimicrobial agents used in aquaculture. Dis Aquat Org 64: 211-222

Milos S, Grbic LM, Dzamic A, Unkovic N, Ristic M, Vukojević J. 2014) Antifungal activity of Helichrysum italicum essential oil against fungi isolated from cultural heritage objects. Arch Biol Sci 66: 1539-1545.

Mireku AE, Mensah YA, Mensah MKL, Ekuadzi E, Dickson AR. 2014. Antimicrobial and Antioxidant Activities of the Stem Bark of Cussonia bancoensis. J Med Biomed Sci 3: 7-13.

Moshi, MJ, Mbwambo, ZH, Nondo, RSO, Masimba, PJ, Kamuhabwa, A, Kapingu, MC, Thomas, P, Richards, M. 2006. Evaluation of ethnomedical claims and brine shrimp toxicity of some plants used in Tanzania as traditional medicines. African J Trad Compl Altern Med 3: 48-58.

Murray PR, Baren EJ, Jorgensen JH, Pfaller MA, Yolken RH. 2003. Manual of Clinical Microbiology. 8th ed. ASM, Washington, D.C.

Mwitari PG, Ayeka PA, Ondicho J, Matu EN, Bii CC. 2013) Antimicrobial Activity and Probable Mechanisms of Action of Medicinal Plants of Kenya: Withania somnifera, Warbugia ugandensis, Prunus africana and Plectrunthus barbatus. Public Lib Sci 8: 1-7.

Nanyingi OM, Mbaria MJ, Lanyasunya L A, Wagate GC, Kipsengeret B K, Kaburia FH, Rahab W M, Ogara O W. 2008. Ethnopharmacological survey of Samburu district, Kenya. J Ethnobiol Ethnomed 4: 14-26.

Ncube NS, Afolayan AJ, Okoh A I. 2008. Assessment techniques of antimicrobial properties of natural compounds of plant origin: current methods and future trends. African J Biotechnol 7: 1797-1806.

Nguta JM, Mbaria JM, Gakuya DW, Gathumbi PK, Kabasa JD, Kiama SG. 2011. Biological Screening of Kenya medical plants using Artemia salina L. (Artemiidae). Pharmacol Online 2: 458-478.

Nguta JM, Mbaria JM. 2013. Brine shrimp toxicity and antimalarial activity of some plants traditionally used in treatment of malaria in Msambweni district of Kenya. J Ethnopharmacol 148: 988-992.

Niranjan MH, Kavitha HU, Sreedharamurthy S, Sudarshana MS. 2010. Antibacterial activity of Schrebera swietenioides against some human pathogenic bacteria. J Pharm Res 3: 1779-1781.

Njoroge GN, Bussmann RW. 2007. Ethnotherapeautic management of skin diseases among the Kikuyus of Central Kenya. J Ethnopharmacol 111: 303-307.

Nor AS, Darah I, Shaida FS, Nurul AZ. 2012. Inhibition of Klebsiella pneumoniae ATCC 13883 cells by hexane extract of Halimeda discoidea (Decaisne) and the identification of its potential bioactive compounds. J Microbiol Biotechnol 22: 872-81.

Nurul ZA, Darah I, Shaida SF, Nor SA. 2010. Screening for antimicrobial activity of various extracts of Acanthophora spicifera (Rhodomelaceae, Ceramiales) from Malaysian waters. Res J Biol Sci 5: 368-375.

Odhiambo J, Dossaji SF, Lukhoba CW, Abiy Y. 2014. Antifungal activity, brine shrimp cytotoxicity, and phytochemical screening of Gladiolus watsonoides Baker (Iridaceae). J Pharm Res 8: 1218-1222

Odhiambo JA, Siboe GM, Lukhoba CW, Dossaji SF. 2010) Antifungal activity of crude extracts of Gladiolus dalenii Van Geel (Iridaceae). African J Trad Compl Altern Med 7: 53-58.

Okoro IO, Auguster O, Edith OA. 2010. Antioxidant and antimicrobial activities of polyphenols from ethnomedicinal plants of Nigeria. African J Biotechnol 9: 2989-2993.

Ozçelik B, Kartal M, Orhan I. 2011. Cytotoxicity, antiviral and antimicrobial activities of alkaloids, flavonoids, and phenolic acids. Pharm Biol 49: 396-402.

Pages JM, James CE, Winterhalter M. 2008. The porin and the permeating antibiotic: A selective diffusion barrier in Gram-negative bacteria. Nat Rev Microbiol 6: 893-903.

Pandey A, Kaushik A, Tiwari SK. 2011. Evaluation of antimicrobial activity and phytochemical analysis of Citrus limon. J Pharmaceut Biomed Sci 13: 1-7.

Pandian, MR, Banu, GS, Kumar, G. 2006. A study of antimicrobial activity of Alanguim salviifolium. Indian J Pharmacol 38: 203-204.

Parekh, J, Chanda, S. (2007. Antibacterial and phytochemical studies on twelve species of Indian medicinal plants. African J Biomed Sci 10: 175-181.

Pazhanisamy M, Ebenezer IGA. 2013. Antioxidant activity of leaves of an important medicinal plant Ormocarpum cochinchinense (Lour.) Merr. J Modern Biotechnol 2: 89-94.

Talib HM, Mahasneh MA. 2010. Antimicrobial, cytotoxicity, and phytochemical screening of Jordanian plants used in traditional medicine. Molecules 15: 1812-1823.

Trease GE, Evans WC. 2002. A Text Book of Pharmacognosy. 15th edition. Academic Press, London.

Wanyoike GN, Chabra SC, Langat CC, Omar SA. 2004. rine shrimp toxicity and antiplasmodial activity of five Kenyan medicinal plants. J Ethnopharmacol 90 129-133.

WHO. 2002. WHO Monographs on Selected Medicinal Plants. Vol. 2, World Health Organization, Geneva, Switzerland.

WHO. 2008 Traditional medicine; growing needs and potential.WHO Policy Perspectives on Medicines. Geneva.

Xu YJ, Capistrano RI, Dhooghe L, Foubert K, Maregesi S, Baldé A, Apers S, Pieters L. 2011. Herbal medicines and infectious diseases: Characterization by LC-SPE-NMR of some medicinal plant extracts used against malaria. Planta Medica 77: 1139-114. 